\title{
Overview of mercury dry deposition, litterfall, and throughfall studies
}

\author{
L. Paige Wright ${ }^{1}$, Leiming Zhang ${ }^{2}$, and Frank J. Marsik ${ }^{3}$ \\ ${ }^{1}$ Independent Researcher, Stratford, Prince Edward Island, Canada \\ ${ }^{2}$ Air Quality Research Division, Science and Technology Branch, Environment and Climate Change Canada, \\ Toronto, Ontario, Canada \\ ${ }^{3}$ Department of Climate and Space Sciences and Engineering, University of Michigan, Ann Arbor, MI, USA
}

Correspondence to: Leiming Zhang (leiming.zhang@ canada.ca)

Received: 3 June 2016 - Published in Atmos. Chem. Phys. Discuss.: 14 June 2016

Revised: 3 October 2016 - Accepted: 6 October 2016 - Published: 31 October 2016

\begin{abstract}
The current knowledge concerning mercury dry deposition is reviewed, including dry-deposition algorithms used in chemical transport models (CTMs) and at monitoring sites and related deposition calculations, measurement methods and studies for quantifying dry deposition of gaseous oxidized mercury (GOM) and particulate bound mercury (PBM), and measurement studies of litterfall and throughfall mercury. Measured median GOM plus PBM dry deposition in Asia $\left(10.7 \mu \mathrm{g} \mathrm{m}^{-2} \mathrm{yr}^{-1}\right)$ is almost double that in North America $\left(6.1 \mu \mathrm{g} \mathrm{m}^{-2} \mathrm{yr}^{-1}\right)$ due to the higher anthropogenic emissions in Asia. The measured mean GOM plus PBM dry deposition in Asia $\left(22.7 \mu \mathrm{g} \mathrm{m}^{-2} \mathrm{yr}^{-1}\right)$, however, is less than that in North America $\left(30.8 \mu \mathrm{g} \mathrm{m}^{-2} \mathrm{yr}^{-1}\right)$. The variations between the median and mean values reflect the influences that single extreme measurements can have on the mean of a data set. Measured median litterfall and throughfall mercury are, respectively, 34.8 and $49.0 \mu \mathrm{g} \mathrm{m}^{-2} \mathrm{yr}^{-1}$ in Asia, 12.8 and $16.3 \mu \mathrm{g} \mathrm{m}^{-2} \mathrm{yr}^{-1}$ in Europe, and 11.9 and $7.0 \mu \mathrm{g} \mathrm{m}^{-2} \mathrm{yr}^{-1}$ in North America. The corresponding measured mean litterfall and throughfall mercury are, respectively, 42.8 and $43.5 \mu \mathrm{g} \mathrm{m}^{-2} \mathrm{yr}^{-1}$ in Asia, 14.2 and $19.0 \mu \mathrm{g} \mathrm{m}^{-2} \mathrm{yr}^{-1}$ in Europe, and 12.9 and $9.3 \mu \mathrm{g} \mathrm{m}^{-2} \mathrm{yr}^{-1}$ in North America. The much higher litterfall mercury than GOM plus PBM dry deposition suggests the important contribution of gaseous elemental mercy (GEM) to mercury dry deposition to vegetated canopies. Over all the regions, including the Amazon, dry deposition, estimated as the sum of litterfall and throughfall minus open-field wet deposition, is more dominant than wet deposition for $\mathrm{Hg}$ deposition. Regardless of the measurement or modelling method used, a
\end{abstract}

factor of 2 or larger uncertainties in GOM plus PBM dry deposition need to be kept in mind when using these numbers for mercury impact studies.

\section{Introduction}

Atmospheric mercury $(\mathrm{Hg})$ exists in three operationally defined forms - gaseous elemental mercury (GEM), gaseous oxidized mercury (GOM), and particulate bound mercury (PBM). Quantification of atmospheric deposition of the three forms of $\mathrm{Hg}$ to various underlying surfaces is needed to assess $\mathrm{Hg}$ effects on sensitive ecosystems and subsequent human health impact. Wet deposition of $\mathrm{Hg}$ can be quantified through analysis of precipitation chemistry (Prestbo and Gay, 2009). While the direct measurement of Hg dry deposition is technically challenging, a number of methods have been developed for approximate $\mathrm{Hg}$ dry deposition, such as micrometeorological, surrogate surface, litterfall, and throughfall measurements (Cobbett and Van Heyst, 2007; Marsik et al., 2007; Graydon et al., 2008; Huang and Gustin, 2015; Risch et al., 2012; Ma et al., 2016).

The approaches used by the above methods to measure mercury dry deposition vary considerably. Efforts are now underway to obtain a better understanding of the variability of estimates from these methods, in an effort to provide a constraint of measurement uncertainties (Marsik et al., 2009; Gustin et al., 2015). The relationships between some of these methods were briefly discussed in Zhang et al. (2012b) and are further illustrated below. Mercury dry deposited to a for- 
est canopy-soil system includes uptake of $\mathrm{Hg}$ by leaf stomata and cuticle, tree bark, and underlying soil. Some of the deposited $\mathrm{Hg}$ may emit back into the atmosphere while some may be translocated to the branches, stems, and roots. Mercury in litterfall includes a portion of the dry-deposited $\mathrm{Hg}$ as well as captured $\mathrm{Hg}$ emitted from the soil, although it may not account for the mercury that has been translocated. Mercury in throughfall includes wet-deposited $\mathrm{Hg}$ above the canopy and a portion of dry-deposited $\mathrm{Hg}$ washed off from the canopy. Thus, litterfall Hg likely represents the low end of $\mathrm{Hg}$ dry deposition when $\mathrm{Hg}$ emission from the underlying soil is small, although it can be higher than the actual dry deposition above the canopy due to the interception of emitted $\mathrm{Hg}$ by forest leaves if soil $\mathrm{Hg}$ emissions are high and the ambient $\mathrm{Hg}$ concentrations above the forests are low. The difference between throughfall and open-area wet deposition, with the former collected inside and the latter outside a forest, should also represent a portion of the dry deposition. Thus, on annual basis, dry deposition can be approximated as the sum of litterfall and throughfall Hg minus wet-deposited $\mathrm{Hg}$.

In chemical transport models (CTMs) and at monitoring sites, $\mathrm{Hg}$ dry deposition is commonly calculated using the inferential method, where it is the product of the dry-deposition velocity and the atmospheric $\mathrm{Hg}$ concentration (Fulkerson, 2006; Lyman et al., 2007; Marsik et al., 2007; Engle et al., 2010; Huang et al., 2012; Zhang et al., 2012b), or using the bi-directional exchange scheme for GEM (Xu et al., 1999; Bash, 2010; Wang et al., 2014; Wright and Zhang, 2015). Development and validation of these schemes need fieldmeasured $\mathrm{Hg}$ dry-deposition data, which unfortunately have larger uncertainties. The magnitudes of uncertainties are expected to be similar between measurement and model estimates (Zhang et al., 2009; Fang et al., 2012b).

The present study provides a detailed review of current knowledge concerning $\mathrm{Hg}$ dry deposition including numerical schemes used in CTMs and at monitoring sites, available field measurements on $\mathrm{Hg}$ dry deposition, and litterfall and throughfall $\mathrm{Hg}$ measurements. Knowledge gained from this study provides guidance for future research directions.

\section{Dry-deposition algorithms and estimation}

\subsection{In chemical transport models}

There are several global and regional chemical transport models from Canada, the United States, Europe, Russia, and Asia that include algorithms for the dry deposition of mercury. A summary of the various models' schemes and their algorithms is provided in Table S1 in the Supplement. In chemical transport models, the approach for the calculation of the dry-deposition velocities of GEM, GOM, and PBM varies between models. For example, in GRAHM (Dastoor et al., 2015), GEOS-Chem (Song et al., 2015), ECHMERIT (De Simone et al., 2014), and GNAQPMS-Hg (Chen et al., 2015), the dry-deposition velocity for GEM is calculated using the multiple resistance analogy approach described in Wesely (1989), Zhang et al. (2003), or Kerkweg et al. (2006). In the case of many regional models, GEM is still not considered in the simulations under the assumption that the dry deposition of GEM is not important considering it is also emitted from the surface, for example WRF/ChemHg (Gencarelli et al., 2015), TEAM (Seigneur et al., 2006), REMSAD (Bullock et al., 2008), and CAMx (De Foy et al., 2014). CMAQ has implemented the bi-directional scheme of Bash (2010) for its treatment of GEM (Bash et al., 2014). Wang et al. (2014) have recently completed a sensitivity analysis of an updated bi-directional air-surface exchange scheme for GEM. A similar resistance analogy for GEM is used to calculate GOM, for example in GRAHM, GEOSChem, and many regional models. In other models, such as WRF/Chem-Hg and CTM-Hg, the dry-deposition velocity of GOM is assumed equal to $\mathrm{HNO}_{3}$ due to their similar solubilities. A number of modelling studies have calculated the drydeposition velocity of PBM using the size-segregated particle dry-deposition model described in L. Zhang et al. (2001) or an earlier dry-deposition and gravitational approach by Slinn and Slinn (1980), including Han et al. (2008), Zhang et al. (2012a), De Simone et al. (2014), and Dastoor et al. (2015). Two other approaches are to set the deposition velocity equal to the deposition velocity of the relatively nonreactive sulfate (Bullock and Brehme, 2002; Christensen et al., 2004; Chen et al., 2015) or to assume specific values over land $\left(0.1 \mathrm{~cm} \mathrm{~s}^{-1}\right)$ and water $\left(0.01 \mathrm{~cm} \mathrm{~s}^{-1}\right)$ (Seigneur et al., 2001, 2004).

The largest major inter-model comparison study, the Intercomparison Study of Numerical Models for LongRange Atmospheric Transport of Mercury, involved eight regional, hemispheric, and global models that compared both short- and long-term simulations over Europe. This intercomparison took place between 2000 and 2005 and was conducted in three phases. The first was an examination of the physical and chemical schemes of Hg (Ryaboshapko et al., 2002); the second phase compared short-term simulations (Ryaboshapko et al., 2007a); and the third phase included simulations over an entire year (Ryaboshapko et al., 2007b). In this latter study, the annual model results conducted over the full year (1999) of the dry deposition of $\mathrm{Hg}$ were within $\pm 50 \%$ of the observations; however, the range of the monthly modelled dry-deposition results varied by up to $\pm 100 \%$ from observations. The large discrepancies observed were attributed to two factors noted earlier: that not all of the models included the dry deposition of GEM and that some models used a fixed deposition velocity over forests for GOM (Ryaboshapko et al., 2007b).

The North American Mercury Model Intercomparison Study involved three regional-scale models (CMAQ, REMSAD, and TEAM) running simulations over North America using the same initial/boundary conditions (Bullock et al., $2008,2009)$. In this study, the dry-deposition results varied 
between the models by close to a factor of 10, with REMSAD producing the smallest dry-deposition fluxes. Only TEAM simulated dry deposition of GEM, but the GEM results were not reported due to the assumption that most of the GEM dry deposited was re-emitted back to the atmosphere (Bullock et al., 2008).

More recently, the Hemispheric Transport of Air Pollution (HTAP) modelling experiment included intercomparisons between GRAHM, GEOS-Chem, GLEMOS, CMAQ-Hg, and ECHMERIT (Travnikov et al., 2010). Hg dry deposition varied between the models, with GEOS-Chem simulating dry-deposition fluxes between $\sim 5 \mu \mathrm{g} \mathrm{m}^{-2} \mathrm{yr}^{-1}$ over the Arctic and almost $30 \mu \mathrm{g} \mathrm{m}^{-2} \mathrm{yr}^{-1}$ over East Asia. For comparison, CTM-Hg fluxes ranged between $\sim 2 \mu \mathrm{g} \mathrm{m}^{-2} \mathrm{yr}^{-1}$ over the Pacific and $\sim 15 \mu \mathrm{g} \mathrm{m}^{-2} \mathrm{yr}^{-1}$ over Europe and North Africa while GRAHM dry-deposition fluxes ranged between $\sim 2 \mu \mathrm{g} \mathrm{m}^{-2} \mathrm{yr}^{-1}$ over the Pacific and $\sim 12 \mu \mathrm{g} \mathrm{m}^{-2} \mathrm{yr}^{-1}$ over East Asia. Over all of the regions, GLEMOS produced the smallest dry-deposition fluxes ranging between $\sim 1 \mu \mathrm{g} \mathrm{m}^{-2} \mathrm{yr}^{-1}$ over the Pacific and $\sim 8 \mu \mathrm{g} \mathrm{m}^{-2} \mathrm{yr}^{-1}$ over East Asia. In this study, mercury deposition results reflected the different model parameterizations. For example, GRAHM simulated higher mercury deposition in the polar regions due to the inclusion of atmospheric mercury depletion events (AMDEs), whereas the incorporation of sea salt aerosol scavenging resulted in higher deposition by GEOS-Chem over oceans (Travnikov et al., 2010). The dry deposition varied by more than an order of magnitude over Europe/North Africa, North America, East Asia, and South Asia. Therefore, Travnikov et al. (2010) recommend the need for more measurements of dry deposition in these regions.

In a regional model study by Zhang et al. (2012a), speciated mercury was modelled over the Great Lakes using CMAQ2002, CMAQ2005, and GRAHM2005. The differences between the estimations of dry deposition of GOM and PBM in the CMAQ models and GRAHM at the regional scale were significant (up to a factor of 2). For all three models, the differences between modelled and measured GOM and PBM concentrations were between factors of 2 and 10, whereas the GEM concentrations were within $30 \%$.

As part of the Global Mercury Assessment (GMA), in 2013, three models (GLEMOS, GEOS-Chem, and GMHG) were used to explore global mercury deposition (Travnikov et al., 2015). These models simulated higher deposition fluxes over industrial sites and regions with higher emissions, similar to trends observed in measurements over China (Fu et al., 2010a). The largest contributions to dry-deposition fluxes of GOM and PBM were over South Asia, East Asia, and Europe. All three models included AMDEs where the highest dry-deposition fluxes in the Arctic were produced in the spring months. The focus of the study of Travnikov et al. (2015) was more to use the three models as an ensemble to examine the global circulation of mercury so the discussion was not on the differences between the models. How- ever, individual results from each model were included in the report. Examples of differences between the models include the relative contribution of domestic and foreign anthropogenic sources to mercury deposition over different regions for 2013. All three models produced the highest contributions in East Asia from domestic anthropogenic sources and in the Arctic from foreign anthropogenic sources. Differences between the models were observed for predicted deposition in Europe, where GLEMOS and GEOS-Chem attributed the largest contribution to domestic sources $(>30$ and $20 \%$, respectively), whereas GMHG had foreign sources as the major contributor. The other region with differences was South Asia, where again GLEMOS and GEOS-Chem had domestic sources as the larger contributor and GMHG had foreign sources as the major contributor.

Challenges still exist in modelling speciated mercury deposition in chemical transport models. These uncertainties come from uncertainties in model-simulated GOM and PBM concentrations (Baker and Bash, 2012; Holloway et al., 2012; Zhang et al., 2012a; Kos et al., 2013), uncertainties in existing dry-deposition algorithms for GOM and PBM, and the lack of proper dry-deposition algorithms for GEM. A better treatment of some of the processes simulated in these models, based on new knowledge generated from analysis of large data sets of recently collected speciated atmospheric data (Cheng et al., 2014, 2015), may improve model performance in simulating GOM and PBM concentrations. For example, the fixed gas-particle partitioning of oxidized $\mathrm{Hg}$ in some models (e.g. GRAHM) can be replaced with temperature-dependant parameterizations described in Cheng et al. (2014). The coarse PBM fraction neglected in many models (Zhang et al., 2012a) should also be addressed since coarse PBM contributes significantly to $\mathrm{Hg}$ dry- and wet-deposition budget (Fang et al., 2012b; Cheng et al., 2015). Validation and implementation of updated bi-directional air-surface exchange schemes into chemistry transport models, such as the one for GEM by Wang et al. (2014), will be beneficial in reducing these uncertainties.

The limited amount of measurement data inhibits the development and improvement of chemical transport models. While speciated mercury data have been increasing rapidly in the recent decade through enhanced monitoring networks (Gay et al., 2013) and increases in field studies (Lindberg and Stratton, 1998; Kim et al., 2009; Maestas, 2011; Fu et al., 2015; Lee et al., 2016), there is no practical way for direct dry-deposition measurement as further illustrated in Section 3. Besides, the monitored oxidized $\mathrm{Hg}$ concentration data, especially GOM, likely have large uncertainties (Jaffe et al., 2014; Gustin et al., 2015) and caution should be made when applying these data for model evaluation (Kos et al., 2013).

\subsection{At monitoring networks/sites}

An increase in the monitoring of speciated atmospheric $\mathrm{Hg}$ in the past decade has led to an increase in the 
number of dry-deposition estimations using the inferential method. There are several monitoring networks that have been established to monitor speciated atmospheric $\mathrm{Hg}$. The largest network to date is the National Atmospheric Deposition (NADP)/Atmospheric Mercury Network (AMNet), which includes more than 30 sites mostly in the United States (Gay et al., 2013). Other networks include the European Monitoring and Evaluation Programme (EMEP) (Travnikov and Ilyin, 2009), the Arctic Monitoring and Assessment Program (AMAP) (Travnikov et al., 2015), and the Global Mercury Observation System (GMOS) (Sprovieri et al., 2013). There have been several monitoring sites which have performed year-long measurement campaigns of $\mathrm{Hg}$ dry deposition of GOM and PBM, such as over 10 sites in Japan (Sakata and Marumoto, 2004, 2005; Sakata and Asakura, 2008) and a number in Taiwan (Fang et al., 2012a, b, 2013, 2014, 2016). A comprehensive review of atmospheric GEM and total gaseous mercury measurements, sites, and trends across the globe can be found in the literature (e.g. Sprovieri et al., 2010). The majority of the Hg dry-deposition studies using the inferential approach and speciated ambient concentrations (referred to as modelled deposition below) were conducted for GOM and PBM (Lindberg and Stratton, 1998; Fulkerson, 2006; Lyman et al., 2007, 2009; Marsik et al., 2007; Han et al., 2008; Engle et al., 2010; Lombard et al., 2011; Castro et al., 2012; Huang et al., 2012; Petersen et al., 2012; Sather et al., 2013; Huang and Gustin, 2015; Fang et al., 2016), while a few studies also included GEM (Rea et al., 2001; Miller et al., 2005; Caldwell et al., 2006; Holmes et al., 2011; Zhang et al., 2012b; Bieser et al., 2014; Enrico et al., 2016). A summary of estimated dry-deposition fluxes for GOM and PBM estimated using the data from the various monitoring networks and other field campaigns is provided in Table S2.

Dry-deposition flux estimations of GOM in North America range from 0.02 to $5.91 \mathrm{ng} \mathrm{m}^{-2} \mathrm{~h}^{-1}$ with one exception in Augusta, Georgia, where the maximum estimated GOM dry-deposition flux was $36.3 \mathrm{ng} \mathrm{m}^{-2} \mathrm{~h}^{-1}$ over vents of a mercury chlor-alkali plant (Landis et al., 2004). In China, the estimation is higher at $20.4 \mathrm{ng} \mathrm{m}^{-2} \mathrm{~h}^{-1}$ (Huang et al., 2012). Dry-deposition flux estimations of PBM range from 0.003 to $4.54 \mathrm{ng} \mathrm{m}^{-2} \mathrm{~h}^{-1}$ in North America and from 0.43 to $46.46 \mathrm{ng} \mathrm{m}^{-2} \mathrm{~h}^{-1}$ in East Asia. In Europe, the median of estimated GOM+PBM dry-deposition fluxes is $0.34 \mathrm{ng} \mathrm{m}^{-2} \mathrm{~h}^{-1}$. In most studies, dry deposition of GOM has been estimated to be much higher than PBM due to the much higher deposition velocities of GOM than PBM (Han et al., 2008; Engle et al., 2010; Huang et al., 2012; Zhang et al., 2012b). Another reason that needs to be emphasized is the exclusion of coarse PBM concentration in the monitoring process in many studies (e.g. Zhang et al., 2012b). Differences between the modelled and measured fluxes are typically at a factor of 2 or larger due to measurement uncertainties and choice of model parameters (Lyman et al., 2007; Marsik et al., 2007; Huang and Gustin, 2015), although some studies obtained very close model-measurement values (Miller et al., 2005; Lyman et al., 2009; Zhang et al., 2012b).

Dry deposition is often assumed to be less important than wet deposition since earlier studies only estimated GOM and PBM dry deposition. Using speciated $\mathrm{Hg}$ data at 19 monitoring sites in North America, Zhang et al. (2012b) estimated speciated and total $\mathrm{Hg}$ dry deposition and also used litterfall $\mathrm{Hg}$ measurements at the regional scale as a constraint for model estimation. In the study of Zhang et al. (2012b), GEM was demonstrated to contribute much more than GOM + PBM to the total dry deposition over vegetated surface. Thus, total dry deposition, when including GEM, was much higher than wet deposition at the majority of the sites, a conclusion that can be supported from litterfall (Risch et al., 2012) and somewhat by throughfall measurements (see more discussion in Sects. 5 and 6).

\section{Deposition (flux), litterfall, and throughfall measurement methodologies}

\subsection{Micrometeorological approaches}

The most common micrometeorological approach employed for the measurement of the air-surface exchange of mercury is the flux-gradient approach. In a common application, time-averaged fluxes of speciated mercury (typically reported in either nanograms (or picograms) per metre squared per hour) are obtained using the relation:

$F_{\mathrm{Hg}, \mathrm{i}}=-K_{Z} \frac{C_{\mathrm{i}}}{Z}$,

where $F_{\mathrm{Hg}, \mathrm{i}}$ is the flux of a given mercury species, $i, K_{Z}$ is the vertical eddy-transfer coefficient and $\frac{C_{\mathrm{i}}}{Z}$ is the timeaveraged vertical gradient of the mercury species, in question. Several approaches have been used to determine the values of the stability-dependent eddy-transfer coefficient $K_{Z}$ including the aerodynamic approach (e.g. Edwards, 2005; Marsik et al., 2005; Fritsche et al., 2008) and the modified Bowen ratio approach (e.g. Kim et al., 1995; Lindberg et al., 1995; Meyers et al., 1996; Poissant et al., 2004; Fritsche et al., 2008). In each case, the assumption is made that all scalar quantities are mixed in a similar fashion within the atmospheric surface layer, and thus the vertical eddy-transfer coefficient for heat (or other tracers, such as $\mathrm{CO}_{2}$ or $\mathrm{H}_{2} \mathrm{O}_{\mathrm{v}}$ ) can be used as a surrogate for the vertical eddy-transfer coefficient for mercury.

The vertical gradient of mercury has been measured using either (a) manual approaches (such as gold-bead traps for GEM, KCl-coated denuders for GOM, and quartz filters for PBM) or (b) automated sampling systems (such as a Tekran ${ }^{\circledR}$ model 2537A mercury vapor analyzer combined with a Tekran ${ }^{\circledR}$ model 1110 synchronized two-port sampling unit for GEM, a Tekran ${ }^{\circledR}$ model 1130 mercury speciation unit for GOM, combined with a Tekran ${ }^{\circledR}$ model 1135 particulate mercury unit for PBM). 


\subsection{Dynamic gas flux chambers}

Dynamic gas chambers, which have been used to study the flux of a number of gaseous species from a variety of emitting surfaces, including leaves, soil, and water, have been successfully employed for use in the measurement of the airsurface exchange of GEM (e.g. Poissant and Casimir, 1998; H. Zhang et al., 2001; Wallschläger et al., 2002; Marsik et al., 2005; Eckley et al., 2011; Edwards and Howard, 2013). In a typical configuration for the measurement of the air-surface exchange of GEM from soil or water surfaces, a polycarbonate flux chamber (DFC) is placed on the emitting surface to be measured. Ambient air is drawn by vacuum through the DFC at a constant flow rate, nominally $1.5 \mathrm{~L} \mathrm{~min}^{-1}$. The concentration of GEM is measured at both the inlet and outlet of the DFC, typically using an automated system, such as a Tekran ${ }^{\circledR}$ model $2537 \mathrm{~A}$ mercury vapor analyzer combined with a Tekran ${ }^{\circledR}$ model 1110 synchronized two-port sampling unit, though initial approaches used manual gold-bead traps. The resulting GEM flux (typically reported in nanograms per metre squared per hour) is calculated using the following relation:

$F_{\mathrm{GEM}}=\left[\frac{\left(C_{\mathrm{O}}-C_{\mathrm{i}}\right) \cdot Q}{A}\right]$,

where $C_{\mathrm{O}}$ is the concentration of GEM at the outlet, $C_{\mathrm{i}}$ is the concentration of GEM at the inlet, $Q$ is the volume flow rate through the DFC, and $A$ is the area of the footprint of the DFC on the surface in question. As with other approaches, the final flux is determined using the above equation, subtracting a sample blank value from measured value. Typically, DFC blanks are obtained at the start and completion of a given sampling period by placing the DFC over a clean, inert surface (e.g. aluminum foil).

\subsection{Surrogate surface approaches}

A number of studies considered in this manuscript have utilized surrogate surface measurement approaches to provide a direct measurement of mercury to the Earth's surface. The designs of the various surrogate surfaces tend to favour the quantification of one form of mercury over the others, while not being able to totally rule out a contribution from one of the other forms. Intercomparison studies have suggested that the different approaches provide relatively consistent results (Marsik, 2009; Gustin et al., 2015), though care must be taken when interpreting surrogate surface results due to the differences in surrogate surface designs.

There are a variety of surrogate surface approaches that have been used to directly measure the dry deposition of mercury. The general classes of approaches can be categorized in the following manner: (a) water/solution-based surfaces, (b) filter-based surfaces, (c) membrane-based surfaces, and (d) turf-based surrogate surfaces. A brief discussion of each of these approaches is presented below.

\subsubsection{Water/solution-based surfaces}

Water- or solution-based surrogate surfaces have been used by a number of groups (Sakata and Marumoto, 2005; Marsik et al., 2007; Lai et al., 2011) for the quantification of the dry deposition of mercury. In general, these approaches deploy a given volume of ultra-pure water in a reservoir that is part of an aerodynamic sampler design. Following a specified period of deployment, the sample solutions are retrieved and the amount of mercury within the sample solution is quantified. In most cases, the final results are "bias-corrected", meaning that the average amount of mercury found in a subset of unexposed solutions is subtracted from the exposed solution to obtain a net amount of mercury which is assumed to be due to that dry deposited to the exposed solution. Some approaches utilize a static amount of solution which is deployed in a fixed reservoir within the sample holder (Marsik et al., 2007; Lai et al., 2011). Other water/solution-based systems approaches use a more dynamic approach for the measurement of the dry deposition of mercury and other species, in which the sample solution is continuously circulated through the sampling apparatus, with the exposed surface area remaining constant through the sample period (e.g. Sakata and Marumoto, 2004).

In general, surrogate water surface approaches using ultrapure water are considered to collect both GOM and PBM, with limited uptake expected from GEM due to the relatively insolubility of this latter species. In most cases, the resultant deposition flux of mercury (in picograms per square metre per hour) is determined by

deposition flux $=\left[\frac{\left(\mathrm{Hg}_{\mathrm{sample}}-\mathrm{Hg}_{\mathrm{blank}}\right)}{A \cdot T}\right]$,

where $\mathrm{Hg}_{\text {Sample }}$ is the amount of mercury in the sample solution, $\mathrm{Hg}_{\text {Blank }}$ is the amount of mercury in the sample blank, $A$ is the exposed surface area of the solution, and $T$ is the length of time over which the sample was exposed to the ambient air.

It should be noted that some approaches use slightly acidified solutions for the purpose of "fixing" deposited mercury to avoid volatilization after deposition to the exposed solution. It is possible that such dilute-acid solutions may lead to an enhanced uptake of GEM due to the fixation of any GEM, which may even temporarily become dissolved in the solution.

\subsubsection{Filter-based surfaces}

A number of filter-based approaches have been used in the collection of mercury dry deposition (Lai et al., 2011). The general concept of this approach is that the three-dimensional structure of the filters will lead to a capture of GOM and PBM. Like the water/solution-based approaches, the filter surfaces are exposed for a given amount of time and then returned to the analytical laboratory at the end of the sampler period, with subsequent quantification of the amount of mer- 
cury deposited to the surface, followed by a bias correction for the average amount of mercury found in a subset of unexposed filters. As before, the mercury dry-deposition flux is quantified as

deposition flux $=\left[\frac{\left(\mathrm{Hg}_{\mathrm{sample}}-\mathrm{Hg}_{\mathrm{blank}}\right)}{A \cdot T}\right]$,

where $\mathrm{Hg}_{\text {Sample }}$ is the amount of mercury on the exposed sample filter, $\mathrm{Hg}_{\text {Blank }}$ is the amount of mercury on the sample filter blank, $A$ is the exposed surface area of the filter, and $T$ is the length of time over which the sample was exposed to the ambient air.

While some of the filter-based approaches utilize the filter surfaces as received from the manufacturer, some approaches coat the filter surfaces either with a solution (that is subsequently allowed to dry) or, in some cases, with a fine film of gold. In these latter cases, the goal is to enhance the collection of GEM mercury that would otherwise be missed by the other filter-based approaches.

\subsubsection{Membrane-based surfaces}

One of the more recently developed approaches uses cation exchange membranes as the exposed deposition surfaces (e.g. Lyman et al., 2007; Castro et al., 2012; Sather et al., 2013; Huang and Gustin, 2015). These membranes have been designed to specifically favour the uptake of GOM over either GEM or PBM, using the assumption that the deposition of mercury is dominated by the former species. This class of filters is typically deployed facing downward, which serves to reduce contamination by large particles and by precipitation. An example of one such filter (Pall Corporation, P / N ICD45S3R) was employed by Lyman et al. (2007) and is constructed out of negatively charged polysulfane on one side and a non-woven polyester backing on the other. As before, the resultant deposition flux of mercury (in picograms per square metre per hour) is determined by

deposition flux $=\left[\frac{\left(\mathrm{Hg}_{\text {sample }}-\mathrm{Hg}_{\text {blank }}\right)}{A \cdot T}\right]$,

where $\mathrm{Hg}_{\text {Sample }}$ is the amount of mercury on the exposed sample filter, $\mathrm{Hg}_{\text {Blank }}$ is the amount of mercury on the sample filter blank, $A$ is the exposed surface area of the filter, and $T$ is the length of time over which the sample was exposed to the ambient air. The inverted sampler design employed with cation exchange membrane samplers protects the membranes from contamination by rainfall, thus allowing these samplers to be deployed for long periods of time and thus providing a long-term integrated measure of $\mathrm{Hg}$ dry deposition.

\subsubsection{Turf surrogate samplers (TSS)}

Much in the way that cation-exchange membrane surfaces were developed in a way that protects them from contamination by rainfall, the TSS approach was developed to allow for dry-deposition measurements to be performed in such a way that the samplers could remain deployed during both dry and precipitating periods (Marsik et al., 2009; Lynam et al., 2015), thus allowing its application for long-term (days to week) quantification of $\mathrm{Hg}$ dry deposition. In addition to reducing the amount of person-hours required to cover surrogate surfaces in the advent of precipitation, this approach also sought to characterize dry deposition to wetted surfaces which can occur following instances of dewfall or rainfall. TSS utilize circular disks of artificial turf (e.g. polyethylene Astro Turf ${ }^{\circledR}$, GrassWorx, LLC, St. Louis, MO), which serve as three-dimensional deposition surfaces. The turf has approximately $2 \mathrm{~cm}$ high polyethylene "blades of grass" which are placed into a Teflon well-style insert (such as that used in the surrogate water-based samplers noted above) that is part of an aerodynamic airfoil. The backing of the turf has a lattice-like construction which allows precipitation to flow through the turf surface into a "throughfall" sample bottle which is included as part of the sample train.

For the period over which the TSS was exposed to ambient air, the estimated dry deposition of mercury is calculated as

dry deposition flux $=\mathrm{Hg}$ flux $_{\mathrm{TSS}}+\mathrm{Hg}$ flux $_{\mathrm{TF}}-\mathrm{Hg}$ flux $_{\mathrm{WO}}$,

where $\mathrm{Hg}$ flux $_{\mathrm{TSS}}$ is the flux of mercury to the TSS over the period of exposure, $\mathrm{Hg}$ flux $\mathrm{TF}_{\mathrm{TF}}$ is the flux of mercury captured within the throughfall bottle, and $\mathrm{Hg}$ flux $_{W O}$ is the flux of mercury captured with a collocated wet-only precipitation sampler. In this case, the wet-only measurement is used to remove the wet-deposited mercury flux from the throughfall measurement, which would contain a combination of both wet- and dry-deposited mercury. All components of the TSS system are acid-cleaned prior to deployment, with field blanks collected for the circular pieces of turf, the throughfall samples, and the wet-only precipitation samples. The appropriate corrections are then made to the data in the determination of the final estimation of the measured flux.

\subsection{Litterfall and throughfall-based approaches}

There are several methods for collecting litterfall: manual sampling of leaves using gloves (Roulet et al., 1998, 1999; Kalicin et al., 2008; Michelazzo et al., 2010; Ding et al., 2011; Juillerat et al., 2012; Obrist et al., 2011, 2012; Melendez-Perez et al., 2014; Jiskra et al., 2015), nylon nets attached to aluminium frames placed a certain distance from the ground (Iverfeldt, 1991; Munthe et al., 1995; Lee et al., 2000; Nóvoa-Muñoz et al., 2008; da Silva et al., 2009; Wang et al., 2009; Fisher and Wolfe, 2012), litterfall traps/collectors (Rea et al., 1996; Grigal et al., 2000; St. Louis et al., 2001; Johnson, 2002; Sheehan et al., 2006; SilvaFilho et al., 2006; Bushey et al., 2008; Graydon et al., 2008; Larssen et al., 2008; Selvendiran et al., 2008; Fu et al., 2010a; Risch et al., 2012; Zhou et al., 2013), funnel and net combinations (Schwesig and Matzner, 2000, 2001), and the use of litterbags (Hall and St. Louis, 2004; Demers et al., 2007; 
Pokharel and Obrist, 2011). Fresh foliage was cut directly from trees and shrubs manually from inside branches and outside branches (McLaughlin et al., 2008), from the crowns of the trees (Mélières et al., 2003; Michelazzo et al., 2010; Blackwell and Driscoll, 2015b; Fostier et al., 2015; Luo et al., 2015), from middle branches (Rasmussen et al., 1991, 1995; Rea et al., 2002; Richardson and Friedland, 2015), from lower tree branches (Michelazzo et al., 2010; Obrist et al., 2012; Gong et al., 2014; Hutnik et al., 2014; Fostier et al., 2015), or shot down with a pellet gun (Bushey et al., 2008; Blackwell and Driscoll, 2015a).

Mercury that is dry deposited to leaves, needle surfaces, branches, and trunks gets washed off during precipitation events. This Hg-enriched rain then lands on the surface and becomes throughfall (Rea et al., 2000, 2001; Mélières et al., 2003; da Silva et al., 2009; Risch et al., 2012). The Hg in the throughfall is then either adsorbed by the litter or forest floor or re-volatilized (Demers et al., 2007). In addition to dry deposition to the leaf/needle surface, foliar leaching was thought to be a possible source of $\mathrm{Hg}$ in throughfall but was found to be negligible (Rea et al., 2001). Throughfall $\mathrm{Hg}$ is calculated by multiplying the volume-mean-weighted $\mathrm{Hg}$ concentration in throughfall by the total throughfall volume. In throughfall field studies, samples are collected weekly (Choi et al., 2008; Wang et al., 2009; Fu et al., 2010a, b; Luo et al., 2015), bi-weekly (Kolka et al., 1999; Grigal et al., 2000; Schwesig and Matzner, 2000; Witt et al., 2009; Åkerblom et al., 2015), monthly (Munthle et al., 1995; Fostier et al., 2000; Lee et al., 2000; Larssen et al., 2008), on an event basis (Rea et al., 2001; Demers et al., 2007; Kalicin et al., 2008), or the funnels are covered between precipitation events to avoid contamination by dry deposition of $\mathrm{Hg}$ on the funnels (Rea et al., 1996). Lengths of campaign measurements vary between a single growing season (Munthe et al., 1995; Rea et al., 1996, 2001; Fostier et al., 2000) to up to a 5-year period (Lee et al., 2000; Porvari and Verta, 2003), with the current majority of throughfall studies having been for a 1-year length (Larssen et al., 2008; Wang et al., 2009; Fu et al., 2010a, b; Fisher and Wolfe, 2012; Åkerblom et al., 2015; Blackwell and Driscoll, 2015b; Luo et al., 2015). The time schedule for throughfall collection is important as there is the opportunity for coniferous forests to scavenge atmospheric $\mathrm{Hg}$ outside of the growing season if the field studies last for longer than just the growing season (Fisher and Wolfe, 2012). The sampling frequency can affect the measured throughfall $\mathrm{Hg}$ as there is the possibility of contamination by $\mathrm{Hg}$ dry deposition occurring if the samplers are not covered during extensive dry periods (Rea et al., 1996). Over long-term studies, however, sample-to-sample throughfall $\mathrm{Hg}$ concentrations may vary on a smaller timescale (i.e. one month) using different sampling frequencies but the cumulative $\mathrm{Hg}$ throughfall deposition will be statistically insignificant (Choi et al., 2008).

\section{Oxidized mercury flux measurements}

Measurements of GEM flux have been reviewed in Zhu et al. (2016) so this section only focuses on GOM and PBM. The majority of the dry-deposition flux measurement campaigns for GOM and PBM (88\%) have used surrogate surface techniques, with $67 \%$ of them being at sites in North America and $33 \%$ of them at sites in Asia. These measurement studies have included several long-term campaigns of up to 3 years in length in both North America (Lyman et al., 2009; Castro et al., 2012; Peterson et al., 2012; WeissPenzias et al., 2012; Sather et al., 2013, 2014; Wright et al., 2014; Huang and Gustin, 2015) and Asia (Sakata and Asakura, 2008; Fang et al., 2016; Han et al., 2016). Current knowledge on particle size distribution of PBM, although limited, has started to be studied in more depth in recent years (Keeler et al., 1995; Ames et al., 1998; Feddersen et al., 2012; Kim et al., 2012). Although PBM mass distributes more in fine $\left(\mathrm{PM}_{2.5}\right)$ than coarse particles $(>2.5 \mu \mathrm{m})$, dry deposition from fine and coarse PBM is equally important due to the faster deposition velocity of coarse particles (Fang et al., 2012a). An increase in North American PBM studies would be beneficial in further exploration of these trends. For a detailed summary of the measured dry-deposition fluxes of GOM and PBM (ng m $\left.{ }^{-2} \mathrm{~h}^{-1}\right)$, as well as the measured concentrations of GOM and PBM $\left(\mathrm{pg} \mathrm{m}^{-3}\right)$, see Table S3.

In North America, the median and mean values are 6.1 and $30.8 \mu \mathrm{g} \mathrm{m}^{-2} \mathrm{yr}^{-1}$ with a range between 0.26 and $520 \mu \mathrm{g} \mathrm{m}^{-2} \mathrm{yr}^{-1}$ (see Table 1). Long-term studies have shown a stronger dependence on GOM dry deposition (40$57 \%$ ) to the total $\mathrm{Hg}$ deposition over arid regions, such as the Four Corners and Nevada (Caldwell et al., 2006; Lyman et al., 2007; Sather et al., 2014), than in more humid regions such as Texas and Oklahoma (5-27\%) and Florida (Lyman et al., 2007; Marsik et al., 2007; Peterson and Gustin, 2008; Weiss-Penzias et al., 2011; 2012; Sather et al., 2014). Higher GOM and PBM concentrations and dry-deposition fluxes have been observed in the close proximity to, or downwind from, point source emissions (Huang et al., 2012; Sather et al., 2014) than at rural sites (Castro et al., 2012; Sather et al., 2014). GOM concentration and dry deposition have shown positive correlations to wind speed (Lyman et al., 2010; Sexauer Gustin et al., 2012; Sather et al., 2014; Huang and Gustin, 2015) and higher elevations (Huang and Gustin, 2015). Diel trends in GOM and PBM have shown higher concentrations in the morning and afternoon (Lindberg and Stratton, 1998; Poissant et al., 2004; Liu et al., 2007; Peterson and Gustin, 2008; Lai et al., 2011; Weiss-Penzias et al., 2011; Sexauer Gustin et al., 2012; Fang et al., 2013; Fu et al., 2016) and then a decrease at night, potentially due to a reduction in photochemical production of GOM at night (Weiss-Penzias et al., 2011) or to nighttime inversion (Huang and Gustin, 2015). The seasonal changes in the fluxes depend on geography and site characteristics where, in general, the fluctuations in the GOM and PBM dry-deposition sea- 
Table 1. Summary of estimated and measured mercury dry deposition and measured mercury in litterfall and throughfall in Asia, Europe, and North America (converted to annual value in the unit of $\mu \mathrm{g} \mathrm{m}^{-2} \mathrm{yr}^{-1}$ ).

\begin{tabular}{|c|c|c|c|c|c|c|c|c|c|}
\hline & \multicolumn{3}{|l|}{ Asia } & \multicolumn{3}{|l|}{ Europe } & \multicolumn{3}{|l|}{ North America } \\
\hline & Median, mean & Range & $n$ & Median, mean & Range & $n$ & Median, mean & Range & $n$ \\
\hline Modelled GOM + PBM & $34.5,83.8$ & $3.8-407$ & 12 & $3.0,3.8$ & $0.1-17.5$ & 27 & $2.6,8.7$ & $0.05-318$ & 157 \\
\hline Measured GOM + PBM & $10.7,22.7$ & $2.4-463$ & 50 & & & & $6.1,30.8$ & $0.26-520$ & 105 \\
\hline Litterfall & $34.8,42.8$ & $4.2-219.9$ & 20 & $12.8,14.2$ & $0.05-42.0$ & 14 & $11.9,12.9$ & $0.02-57.1$ & 92 \\
\hline Throughfall & $49.0,43.5$ & $10.5-71.3$ & 11 & $16.3,19.0$ & $12-40.1$ & 17 & $7.0,9.3$ & $2.1-26.6$ & 32 \\
\hline
\end{tabular}

sonal variations have been observed to be more pronounced in arid regions. Higher GOM deposition has been observed in the spring due to GOM events and long-range transport (Liu et al., 2007; Lyman et al., 2009; Weiss-Penzias et al., 2011; Castro et al., 2012; Sexauer Gustin et al., 2012; Peterson et al., 2012; Sather et al., 2013; Huang and Gustin, 2015).

There are some physical aspects of the various measurement techniques that have been observed to affect measured values. The direction that the filter in the cation-exchange membrane is facing can alter amount of deposited particles, with lower measured dry-deposition fluxes of GOM and PBM in downward facing membranes (Lyman et al., 2007, 2009; Weiss-Penzias et al., 2011; Sexauer Gustin et al., 2012; Huang et al., 2012; Peterson et al., 2012; Sather et al., 2013, 2014; Huang and Gustin, 2015) than upward facing (Huang et al., 2012). In addition to direction of the membrane, higher deposition rates have been observed for rectangular mounts than aerodynamic mounts, possibly due to artificial turbulence created by the rectangular mounts (Lyman et al., 2009). The length of deployment times for surrogate surfaces is under debate, with recommendations that a minimum sampling time of 2 weeks be implemented at rural sites (Huang et al., 2012; Huang and Gustin, 2015) and for passive samplers (Lyman et al., 2010). Improvements and changes in sampling techniques continue. For example, the ICE 450 passive sampler, used in several GOM studies (e.g. Castro et al., 2012; Huang et al., 2012; Sather et al., 2013, 2014), was replaced in July 2013 with the Mustang S passive sampler (Huang and Gustin, 2015), where fortunately no significant differences in the measurement results from the two samplers have been observed (Huang and Gustin, 2015). Clearly, surrogate surfaces may differ significantly from the real-world natural surfaces, and choices of surrogate surfaces and instrument setup can both affect the measured deposition values.

In Asia, dry-deposition fluxes of GOM + PBM are higher than in North America where median and mean values are 10.7 and $22.7 \mu \mathrm{g} \mathrm{m}^{-2} \mathrm{yr}^{-1}$, with a range between 2.4 and $463 \mu \mathrm{g} \mathrm{m}^{-2} \mathrm{yr}^{-1}$. Similar to North America, in Asia, GOM and PBM concentrations and dry-deposition fluxes have been observed to be up to 5 times greater at urban and industrial sites due to the close proximity to, or downwind from, point source emissions (Sakata and Marumoto, 2005; Liu et al., 2007; Sakata and Asakura, 2008; Fang et al., 2012a) than at rural sites (Sakata and Marumoto, 2005; Sakata and Asakura, 2008). At three sites in Taiwan, PBM concentrations were highest in November and December and in the summer due to industry, such as coal-fired power plants, and GOM events (Fu et al., 2016). Higher PBM has been measured in the winter due to increases in the winter in the use of vehicles, biomass burning, and electricity consumption such as home heating or due to an accumulation in PBM because of lower temperatures and solar radiation (Sakata and Asakura, 2008; Fang et al., 2012a; Fu et al., 2016; Han et al., 2016).

\section{Litterfall measurements}

Litterfall $\mathrm{Hg}$ represents $\mathrm{Hg}$ collected by and retained in leaves. It has been observed in recent years to be an important pathway for $\mathrm{Hg}$ input from the atmosphere to the floor of forest ecosystems via plant litter. Litterfall is comprised of senesced leaves and needles, twigs, and branches, and other plant tissues. Litterfall $\mathrm{Hg}$ can be transmitted to the soil as the litter decomposes. Litterfall $\mathrm{Hg}$ is determined by the concentration of $\mathrm{Hg}$ in the leaf litter (Rea et al., 1996; Sheehan et al., 2006; Silva-Filho et al., 2006; Wang et al., 2009; Niu et al., 2011). Another method for estimating litterfall $\mathrm{Hg}$ has been to multiply the $\mathrm{Hg}$ concentration in fresh foliage by 1.5 to account for the assumption that the $\mathrm{Hg}$ accumulates in the leaf linearly over an average 6-month growing season (Fu et al., 2010b; Gong et al., 2014). It is important to note that a litterfall deposition value estimated through multiplying the fresh foliage value by 1.5 does have an associated error factor that comes with it. Litterfall measurement campaigns have ranged from the growing season (Rea et al., 1996, 2002; Fostier et al., 2003; Larssen et al., 2008; Ding et al., 2011; Fisher and Wolfe, 2012) to long-term studies of a year (Schwesig and Matzner, 2000, 2001; St. Louis et al., 2001; de Oliveira et al., 2005; Silva-Filho et al., 2006; Sheehan et al., 2006; da Silva et al., 2009; Wang et al., 2009; Fu et al., 2010a; Teixeira et al., 2012; Zhou et al., 2013; Lang, 2014; Luo et al., 2015 ) to 2 years or more (Xiao et al., 1998; Lee et al., 2000; Hall and St. Louis, 2004; Graydon et al., 2008; Selvendiran et al., 2008; Obrist et al., 2011; Risch et al., 2012; Hutnik et al., 2014; Blackwell and Driscoll, 2015b; Richardson and Friedland, 2015). A summary of available measurements of $\mathrm{Hg}$ concentrations in leaves and litter $\left(\mathrm{ng} \mathrm{g}^{-1}\right)$ and litterfall $\mathrm{Hg}\left(\mu \mathrm{g} \mathrm{m}^{-2} \mathrm{yr}^{-1}\right)$ is provided in Table S4. 
Litterfall $\mathrm{Hg}$ measurements are highest in Asia, where the median and mean values from 20 sites (34.8 and $42.8 \mu \mathrm{g} \mathrm{m}^{-2} \mathrm{yr}^{-1}$, respectively) are approximately 2 to 3 times higher than the measured litterfall $\mathrm{Hg}$ in Europe over 14 sites (12.8 and $14.2 \mu \mathrm{g} \mathrm{m}^{-2} \mathrm{yr}^{-1}$, respectively) and more than 3 times higher than in North America over 92 sites (11.9 and $12.9 \mu \mathrm{g} \mathrm{m}^{-2} \mathrm{yr}^{-1}$, respectively) (as shown in Table 1). Litterfall $\mathrm{Hg}$ ranges from $4.2-219.9 \mu \mathrm{g} \mathrm{m}^{-2} \mathrm{yr}^{-1}$ in Asia to $0.05-42 \mu \mathrm{g} \mathrm{m}^{-2} \mathrm{yr}^{-1}$ in Europe. In North America, litterfall $\mathrm{Hg}$ ranges between 0.02 and $57.1 \mu \mathrm{g} \mathrm{m}^{-2} \mathrm{yr}^{-1}$, respectively. Measurements of litterfall $\mathrm{Hg}$ in the Amazonian rainforest have been reviewed in detail by Fostier et al. (2015). Atmospheric $\mathrm{Hg}$ concentrations affect the levels of $\mathrm{Hg}$ concentrations in foliage and leaf litter with higher litterfall $\mathrm{Hg}$ in urban forests than remote forests (Fostier et al., 2003; 2015; Wang et al., 2009; Fu et al., 2010a, b; Gong et al., 2014); higher $\mathrm{Hg}$ concentrations in close proximity to degassing vents and during eruption activity of volcanoes (Martin et al., 2012); and higher $\mathrm{Hg}$ concentrations at intermediate altitudinal mountain zones (Szopka et al., 2011). It is important to note, however, that the atmospheric $\mathrm{Hg}$ concentration is not the only factor that affects the levels of $\mathrm{Hg}$ concentrations in foliage and leaf litter, as discussed below. In Europe, a decrease in litterfall $\mathrm{Hg}$ has been associated with the decrease in $\mathrm{Hg}$ emissions in recent years (Larssen et al., 2008).

Due to coniferous needles remaining on trees for longer periods than deciduous trees (years vs. one season), needle litter tends to have higher $\mathrm{Hg}$ concentrations than leaf litter (Grigal et al., 2000; Sheehan et al., 2006; Niu et al., 2011; Blackwell and Driscoll, 2015b; Fisher and Wolfe, 2012; Obrist et al., 2012). This, however, does not translate directly to higher litterfall $\mathrm{Hg}$ in coniferous forests due to the contribution from the higher mass of leaf litter than needle litter. As a result, litterfall $\mathrm{Hg}$ in deciduous forests has been found to be higher than in coniferous forests (Schwesig and Matzner, 2000; Demers et al., 2007; Kalicin et al., 2008; Fisher and Wolfe, 2012; Obrist et al., 2012; Richardson and Friedland, 2015).

Correlations between $\mathrm{Hg}$ concentrations and age of the foliage have been observed with concentrations increasing with age (Barghigiani et al., 1991; Roulet et al., 1999; Ericksen et al., 2003; Larssen et al., 2008; Ding et al., 2011; Martin et al., 2012) and higher in litter than foliage (Iverfeldt, 1991; Bushey et al., 2008; Michelazzo et al., 2010; Ding et al., 2011; Melendez-Perez et al., 2014; Luo et al., 2015).

In three urban forests in Asia, annual litterfall $\mathrm{Hg}$ deposition was found to account for up to $75 \%$ of the total $\mathrm{Hg}$ input fluxes to the forests (Wang et al., 2009). The contribution of $\mathrm{Hg}$ from litterfall has been found to be 3 times the amount from throughfall (Fu et al., 2010a) and anywhere from 2 times up to 14 times the contribution from wet deposition (Wang et al., 2009; Fu et al., 2010a; Zhou et al., 2013). A detailed review of litterfall, throughfall, and precipitation studies in China can be found in Fu et al., 2015. In Europe, litterfall $\mathrm{Hg}$ has been found to represent between 27 and $90 \%$ to the total deposited $\mathrm{Hg}$ (Schwesig and Matzner, 2000, 2001; Jiskra et al., 2015), from equal to 1.5 times the deposited throughfall $\mathrm{Hg}$ and 2 times the open-field precipitation (Iverfeldt et al., 1991; Munthe et al., 1995; Lee et al., 2000). In the Amazonian rainforest, litterfall $\mathrm{Hg}$ has been observed to be twice the contribution from wet deposition (da Silva et al., 2009) and more than doubled during the dry season (Silva-Filho et al., 2006). In North America, some studies have found contributions to the deposition flux from litterfall and throughfall equal (Iverfeldt et al., 1991; Rea et al., 1996; Grigal et al., 2000; Lee et al., 2000), whereas in other studies litterfall has contributed up to 2 times more $\mathrm{Hg}$ than throughfall (St. Louis et al., 2001; Johnson, 2002; Fisher and Wolfe, 2012).

Median litterfall deposition of $12.3 \mu \mathrm{g} \mathrm{m}^{-2} \mathrm{yr}^{-1}$ accounted for $55 \%$ of the $\mathrm{Hg}$ deposition to deciduous forest floors at 23 sites in eastern USA (Risch et al., 2012). In this study that spanned 15 states over 3 years, litterfall $\mathrm{Hg}$ ranged between 3.5 and $23.4 \mu \mathrm{g} \mathrm{m}^{-2} \mathrm{yr}^{-1}$. Litterfall $\mathrm{Hg}$ was found to be more correlated to the amount of litter collected (i.e. the sample catch) than $\mathrm{Hg}$ wet deposition, with the highest median litterfall $\mathrm{Hg}$ deposition $\left(14.7 \mu \mathrm{g} \mathrm{m}^{-2} \mathrm{yr}^{-1}\right)$ found in deciduous forests. Mixed forests and coniferous forests had the same median litterfall $\mathrm{Hg}$ concentration (38.6 $\mathrm{ng} \mathrm{g}^{-1}$ ) but the mixed forest litterfall $\mathrm{Hg}$ was higher (9.3 vs. $7.0 \mu \mathrm{g} \mathrm{m}^{-2} \mathrm{yr}^{-1}$ ) due to the higher sample catch. Of the deciduous sites, oak-hickory forests had higher litterfall $\mathrm{Hg}$ than maple-beech-birch forests and aspen-birch forests. Litterfall $\mathrm{Hg}$ deposition was more dependent on the forest cover type than geographical region. Intraseasonal variations were observed with higher litterfall $\mathrm{Hg}$ concentrations in the first autumn sampling than the second. Interannual variations were observed for the sample catch but were not significant for litterfall $\mathrm{Hg}$ concentrations.

\section{Throughfall measurements}

Factors that affect throughfall $\mathrm{Hg}$ deposition include canopy type, with higher concentrations in coniferous canopies than deciduous canopies due to a combination of higher $\mathrm{Hg}$ scavenging efficiency in coniferous forests over deciduous forests and larger surface areas (Kolka et al., 1999; Rea et al., 1996; Grigal et al., 2000; Schwesig and Matzner, 2000, 2001; Johnson, 2002; Demers et al., 2007; Wang et al., 2009; Fu et al., 2010a, b; Fisher and Wolfe, 2012; Åkerblom et al., 2015; Luo et al., 2015); canopy density, with $\mathrm{Hg}$ throughfall concentrations increasing with canopy density (Grigal et al., 2000; Witt et al., 2009); meteorology, with higher throughfall concentrations under drier conditions, resulting from increased dry deposition to the foliage (Blackwell and Driscoll, 2015b); and location, with higher concentrations in regions with high atmospheric $\mathrm{Hg}$ emissions or close to point sources, such as urban forests (Wang et al., 2009; Luo et al., 2015). A summary of available measurements $\mathrm{Hg}$ concentrations in throughfall 

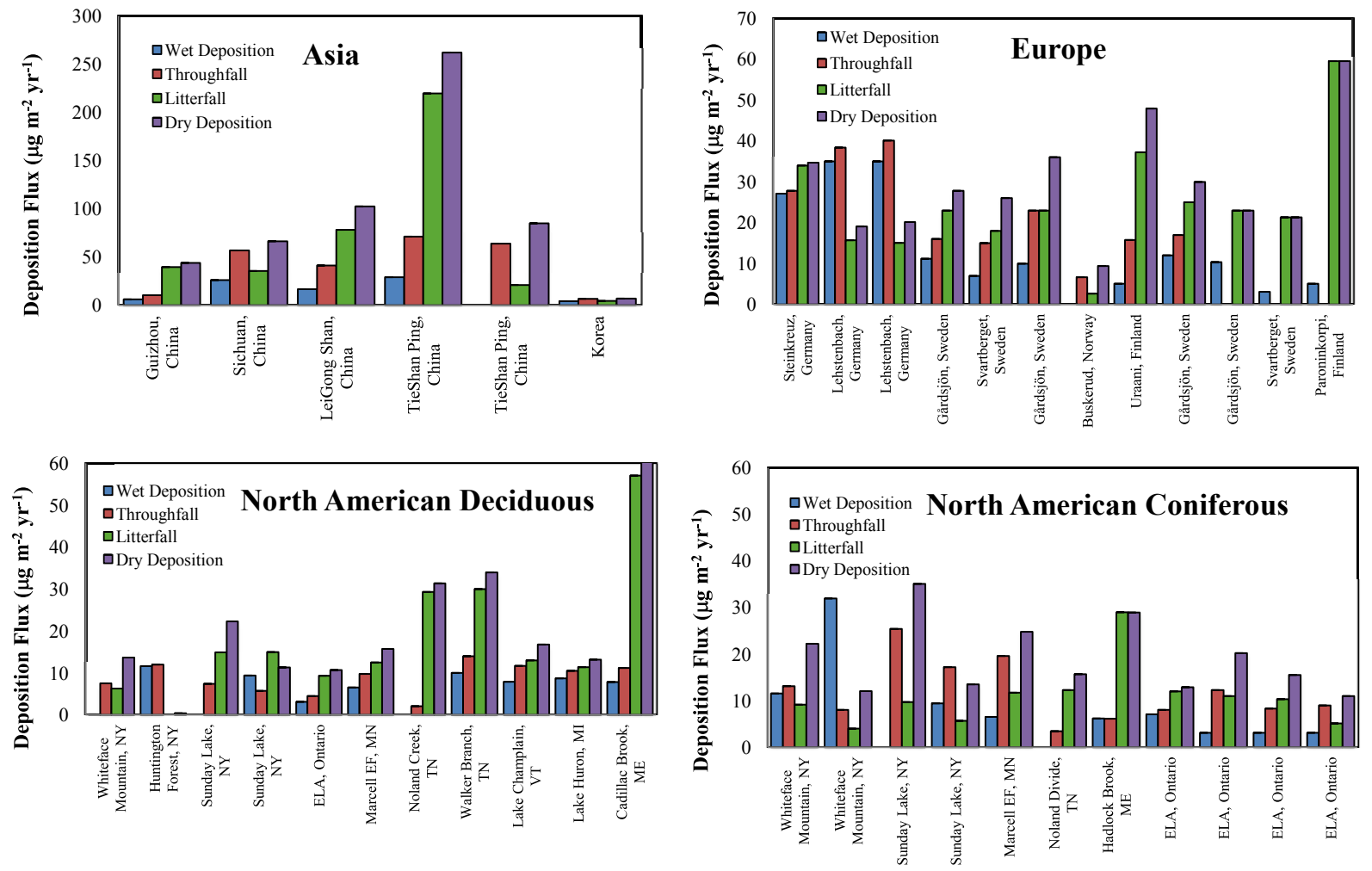

Figure 1. Contributions to the mercury deposition flux $\left(\mu \mathrm{g} \mathrm{m}^{-2} \mathrm{yr}^{-1}\right.$ ) from wet deposition, throughfall $\mathrm{Hg}$, litterfall $\mathrm{Hg}$, and dry deposition in Asia, Europe, and North American deciduous forests and North American coniferous forests. References in order of appearance: Fu et al. (2010a, b); Wang et al. (2009); Luo et al. (2015); Schwesig and Matzner (2000, 2001); Hultberg et al. (1995); Lee et al. (2000); Larssen et al. (2008; Porvari and Verta, 2003; Iverfeldt, 1991; Lee et al. (1998); Blackwell and Driscoll (2015b); Choi et al. (2008); Demers et al. (2007); Kalicin et al. (2007); Graydon et al. (2008); Grigal et al. (2000); Fisher and Wolde (2012); Lindberg et al. (1996); Rea et al. (1996, 2001); Johnson et al. (2007); St. Louis et al. (2001).

(ng L ${ }^{-1}$ ) and throughfall $\mathrm{Hg}\left(\mu \mathrm{g} \mathrm{m}^{-2} \mathrm{yr}^{-1}\right)$ is provided in Table S5.

In Asia, median and mean throughfall $\mathrm{Hg}$ for this region are 49.0 and $43.5 \mu \mathrm{g} \mathrm{m}^{-2} \mathrm{yr}^{-1}$, respectively, with a range of means between 10.5 and $71.3 \mu \mathrm{g} \mathrm{m}^{-2} \mathrm{yr}^{-1}$. These median and mean are more than 2 to 3 times the European values (16.3 and $19.0 \mu \mathrm{g} \mathrm{m}^{-2} \mathrm{yr}^{-1}$ for the median and mean, respectively), where the range is between 12.0 and $40.1 \mu \mathrm{g} \mathrm{m}^{-2} \mathrm{yr}^{-1}$ (as shown in Table 1). For throughfall, the median and mean throughfall $\mathrm{Hg}$ in Asia are 8 and 5 times larger, respectively, than those reported in North America, likely due to heavier atmospheric $\mathrm{Hg}$ loadings in Asia than North America (Fu et al., 2010b). Fu et al. (2010b) found that while the throughfall in remote regions of China were smaller than in urban regions of China, they were still up to 2 times higher than in remote regions of North America. Industrial and urban pollution, density of the population, and coal combustion and mining have all resulted in China having the highest $\mathrm{Hg}$ emissions in the world (Wang et al., 2009; Fu et al., 2010a; Fu et al., 2015). A modelling study by Seigneur et al. (2003) found that $\mathrm{Hg}$ emissions from Asia were the largest contributor outside of the United States to Hg deposi- tion in New York due to long-range transport. This is similar to detailed discussions in Fu et al. (2015) on the effects of trends in increasing $\mathrm{Hg}$ emissions in China on the patterns of long-range transport. In North America, the median and mean values are the lowest at 7.0 and $9.3 \mu \mathrm{g} \mathrm{m}^{-2} \mathrm{yr}^{-1}$, respectively, with a range between 2.1 and $26.6 \mu \mathrm{g} \mathrm{m}^{-2} \mathrm{yr}^{-1}$. The only throughfall $\mathrm{Hg}$ measurement in South America is an estimate of $72.0 \mathrm{\mu g} \mathrm{m}^{-2} \mathrm{yr}^{-1}$ in the Brazilian Amazon (Fostier et al., 2000), which has been suggested to be an overestimation due to the temporal sampling distribution where higher $\mathrm{Hg}$ concentrations were observed in samples that had a dry period of several days immediately prior to sampling. Without any other Amazonian throughfall studies, it is not known whether this is a typical value for this rainforest or if the high value was related to the monthly collection. In Asia and Europe, $\mathrm{Hg}$ contributions from throughfall are higher than from wet deposition, with throughfall ranging from approximately 2 to 4 times the wet deposition (Munthe et al., 1995, Lee et al., 2000; Fu et al., 2010a; 2010b; Wang et al., 2009). In North America, the throughfall-precipitation ratio has been found to differ with forest type, where, based upon throughfall measurements, dry deposition was found to be 
less than wet deposition in deciduous forests (Demers et al., 2007; Kalicin et al., 2008; Blackwell and Driscoll, 2015b) and greater than precipitation in coniferous forests (Demers et al., 2007; Kalicin et al., 2008; Witt et al., 2009) and over watersheds (Lindberg et al., 1994; Rea et al., 1996, 2001; Grigal et al., 2000; Graydon et al., 2008).

\section{A brief comparison of dry, litterfall, throughfall, and wet deposition}

The annual contributions to $\mathrm{Hg}$ deposition from wet deposition, throughfall, litterfall, and dry deposition $\left(\mu \mathrm{g} \mathrm{m}^{-2} \mathrm{yr}^{-1}\right)$ are shown in Fig. 1 for various sites in (a) Asia, (b) Europe, (c) North American deciduous forests, and (d) North American coniferous forests. Figure 1 includes sites for which measurements for litterfall, throughfall, and dry and wet deposition have all been measured. This figure is provided to give a representation of the range of values for the various measurement methods. In these figures, the wet deposition represents open-field wet-deposition measurements, with the exception of the measurements at Whiteface Mountain in the Adirondack Park, NY (Blackwell et al., 2015b), where the wet deposition is from cloud water. The estimated dry deposition shown in this figure is the sum of the litterfall $\mathrm{Hg}$ and throughfall $\mathrm{Hg}$ minus the wet-deposited $\mathrm{Hg}$.

In China, dry deposition accounted for between $25 \%$ and $90 \%$ of the total $\mathrm{Hg}$ deposited to subtropical forested catchments. Litterfall $\mathrm{Hg}$ was the dominant pathway in these forests contributing between 53 and $90 \%$ of the dry deposition to these forests. In forested watersheds in Germany, wet deposition played a stronger role, accounting for $78 \%$ of the total $\mathrm{Hg}$ deposition in Steinkreuz and almost twice as much at Lehstenbach. At the other European sites, wet deposition only represented between 9 and $45 \%$ of the total $\mathrm{Hg}$ deposition. At all of the European sites, litterfall $\mathrm{Hg}$ was the dominant pathway at 64 to $98 \%$ of the dry-deposited $\mathrm{Hg}$, with the exception of Buskerud, Norway, where wet deposition was not reported, preventing an accurate estimate of dry deposition (Larssen et al., 2008). In North America, the dry deposition of $\mathrm{Hg}$ ranged between 13 and $83 \%$ of the total deposited $\mathrm{Hg}$ over deciduous forests and 15 and $70 \%$ over coniferous forests, with the primary factor in these variances being proximity to sources. Exceptions to these values were at Whiteface Mountain, as mentioned above, where wet deposition is reported as high-elevation cloud water $\mathrm{Hg}$ rather than openfield precipitation. The contributions from net throughfall $\mathrm{Hg}$ (throughfall $\mathrm{Hg}$-wet deposition) were higher in the coniferous forests than the deciduous forests. In the deciduous forests, litterfall $\mathrm{Hg}$ accounted for between 46 and $95 \%$ of total deposited $\mathrm{Hg}$.

\section{Summary and recommendations}

The modelling of GOM and PBM dry deposition on regional and global scales using various chemical transport models shows inconsistencies between the models, up to a factor of 10 in some cases, which are caused by differences in model simulated GOM and PBM concentrations and in selected dry-deposition algorithms. Recent analysis of large data sets of speciated atmospheric mercury has provided some needed knowledge for improving these models. However, measurement uncertainties in ambient GOM and PBM concentrations, and the significant lack of measurements over the oceans, the polar regions, the Southern Hemisphere, Europe, and Asia are inhibiting further evaluation of the models. Progress has been made on the inferential estimation of speciated and total $\mathrm{Hg}$ dry deposition at monitoring sites or networks. GEM deposition to forest canopies is more important than previously assumed in chemical transport models. Further development of dry-deposition algorithms, especially the bi-directional exchange for GEM, is still needed, but reliable $\mathrm{Hg}$ flux data are lacking in validating such models.

Surrogate surfaces are the current preferred method for measuring the dry deposition of GOM and PBM, with a new turf surrogate surface showing promise in extending the length of the sampling times to longer campaigns. Uncertainties in the measured GOM and PBM dry deposition associated with the selected surrogate surfaces and instrument setup are larger than a factor of 2. Measurements of PBM dry deposition are very limited around the world due to the challenges associated with making these measurements. Measured GOM and PBM dry deposition are strongly correlated to emissions from local point sources due to their short lifetime in air. GOM deposition can play a significant role in total $\mathrm{Hg}$ deposition, contributing to more than half of $\mathrm{Hg}$ dry deposition in some regions, and having been found to be higher than wet deposition in some arid regions and lower in more humid regions due to the high solubility of GOM.

There has been a large increase in the number of field campaigns measuring litterfall and throughfall mercury in Asia, Europe, the Amazon, and North America. Generally, litterfall and throughfall $\mathrm{Hg}$ are higher in urban regions of Asia as a result of the high levels of atmospheric $\mathrm{Hg}$ in Asia, followed by remote regions in Asia, then Europe, and North America. As can be seen in North American field studies, litterfall $\mathrm{Hg}$ is more dominant than throughfall $\mathrm{Hg}$ over deciduous canopies due to the larger amounts of litter under these canopies, whereas throughfall is the primary pathway for mercury deposition over coniferous canopies. Net throughfall $\mathrm{Hg}$ is the throughfall $\mathrm{Hg}$ minus the $\mathrm{Hg}$ in precipitation. This deposition, combined with the deposition of litterfall $\mathrm{Hg}$ is higher than the precipitation $\mathrm{Hg}$ over all canopies and regions. The measurement of litterfall, throughfall, and openfield precipitation $\mathrm{Hg}$, and the subsequent comparison with modelled $\mathrm{Hg}$ dry deposition, is an effective way of improv- 
ing our understanding of the mechanisms involved in these transfers.

\section{Data availability}

Data presented in this study were all generated from published literature and are available from the original researchers.

\section{The Supplement related to this article is available online at doi:10.5194/acp-16-13399-2016-supplement.}

Acknowledgements. We appreciate all of the people who have contributed to the data collection and quality control for the AMNet and MDN data sets that are used in the present study. We appreciate the anonymous reviewers for their constructive comments that have improved our paper.

Edited by: R. Ebinghaus

Reviewed by: two anonymous referees

\section{References}

Åkerblom, S., Meili, M., and Bishop, K.: Organic Matter in Rain: An Overlooked Influence on Mercury Deposition, Environ. Sci. Technol. Lett., 2, 128-132, 2015.

Ames, M., Gullug, G., and Olmez, I.: Atmospheric mercury in the vapor phase, and in fine and coarse particulate matter at Perch River, New York, Atmos. Environ., 32, 865-872, 1998.

Baker, K. R. and Bash, J. O.: Regional scale photochemical model evaluation of total mercury wet deposition and speciated ambient mercury, Atmos. Environ., 49, 151-162, 2012.

Barghigiani, C., Ristori, T., and Cortopassi, M.: Air mercury measurement and interference of atmospheric contaminants with gold traps, Environ. Technol., 12, 935-941, 1991.

Bash, J. O.: Description and initial simulation of a dynamic bidirectional air-surface exchange model for mercury in Community Multiscale Air Quality (CMAQ) model, J. Geophys. Res., 115, D06305, doi:10.1029/2009JD012834, 2010.

Bash, J. O., Carlton, A. G., Hutzell, W. T., and Bullock Jr., O. R.: Regional Air Quality Model Application of the Aqueous-Phase Photo Reduction of Atmospheric Oxidized Mercury by Dicarboxylic Acids, Atmosphere, 5, 1-15, doi:10.3390/atmos5010001, 2014.

Bieser, J., De Simone, F., Gencarelli, C., Geyer, B, Hedgecock, I., Matthias, V., Travnikov, O., and Weigelt, A.: A diagnostic evaluation of modeled mercury wet depositions in Europe using atmospheric speciated high-resolution observations, Environ. Sci. Pollut. R., 21, 9995-10012, 2014.

Blackwell, B. D. and Driscoll, C. T.: Using foliar and forest floor mercury concentrations to assess spatial patterns of mercury deposition, Environ. Pollut., 202, 126-134, 2015a.
Blackwell, B. D. and Driscoll, C. T.: Deposition of mercury in forests along a montane elevation gradient, Environ. Sci. Technol., 49, 5363-5370, 2015b.

Bullock Jr. and Brehme, K. A.: Atmospheric mercury simulation using the CMAQmodel: formulation description and analysis of wet deposition results, Atmos. Environ., 36, 2135-2146, 2002.

Bullock Jr., O. R., Atkinson, D., Braverman, T., Civerolo, K., Dastoor, A., Davignon, D., Ku, J.-Y., Lohman, K., Myers, T. C., Park, R. J., Seigneur, C., Selin, N. E., Sistla, G., and Vijayaraghavan, L.: The North American Mercury Model Intercomparison Study (NAMMIS): Study description and model-to-model comparisons, J. Geophys. Res., 113, D17310, doi:10.1029/2008JD009803, 2008.

Bullock Jr., O. R., Atkinson, D., Braverman, T., Civerolo, K., Dastoor, A., Davignon, D., Ku, J.-Y., Lohman, K., Myers, T. C., Park, R. J., Seigneur, C., Selin, N. E., Sistla, G., and Vijayaraghavan, L.: An analysis of simulated wet deposition of mercury from the North American Mercury Model Intercomparison Study, J. Geophys. Res., 114, D08301, doi:10.1029/2008JD011224, 2009.

Bushey, J. T., Nallana, A. G., Montesdeoca, M. R., and Driscoll, C. T.: Mercury dynamic of a northern hardwood canopy, Atmos. Environ., 42, 6905-6914, 2008.

Caldwell, C. A., Swartzendruber, P., and Prestbo, E.: Conecntration and dry deposition of mercury species in arid south central New Mexico (2001-2002), Environ. Sci. Technol., 40, 75357540, 2006.

Castro, M. S., Moore, C., Sherwell, J., and Brooks, S. B.: Dry deposition of gaseous oxidized mercury in Western Maryland, Sci. Total Environ., 417-418, 232-240, 2012.

Chen, H. S., Wang, Z. F., Li, J., Tang, X., Ge, B. Z., Wu, X. L., Wild, O., and Carmichael, G. R.: GNAQPMS-Hg v1.0, a global nested atmospheric mercury transport model: model description, evaluation and application to trans-boundary transport of Chinese anthropogenic emissions, Geosci. Model Dev., 8, 2857-2876, doi:10.5194/gmd-8-2857-2015, 2015.

Cheng, I., Zhang, L., Blanchard, P: Regression modeling of gasparticle partitioning of atmospheric oxidized mercury from temperature data, J. Geophys. Res.-Atmos., 119, 11864-11876, 2014.

Cheng, I., Zhang, L., and Mao, H.: Relative contributions of gaseous oxidized mercury and fine and coarse particle-bound mercury to mercury wet deposition at nine monitoring sites in North America, J. Geophys. Res.-Atmos., 120, 8549-8562, 2015.

Choi, H.-D., Sharac, T. J., and Holsen, T. M.: Mercury deposition in the Adirondacks: A comparison between precipitation and throughfall, Atmos. Environ., 42, 1818-1827, 2008.

Christensen, J. H., Brandt, J., Frohn, L. M., and Skov, H.: Modelling of Mercury in the Arctic with the Danish Eulerian Hemispheric Model, Atmos. Chem. Phys., 4, 2251-2257, doi:10.5194/acp-42251-2004, 2004.

Cobbett, F. D. and Van Heyst, B. J.: Measurements of GEM fluxes and atmospheric mercury concentrations (GEM, RGM and Hgp) from an agricultural field amended with biosolids in Southern Ont., Canada (October 2004-November 2004), Atmos. Environ., 41, 2270-2282, 2007.

da Silva, G. S., Bisinoti, M. C., Fadini, P. S., Magarelli, G., Jardim, W. F., and Fostier, A. H. : Major Aspects of the Mercury Cycle in the Negro River Basin, Amazon, J. Brazil. Chem. Soc., 20, 1127-1134, 2009. 
Dastoor, A., Ryzhkov, A., Durnford, D., Lehnherr, I., Steffen, A., and Morrison, H.: Atmospheric mercury in the Canadian Arctic. Part II: Insight from modeling, Sci. Total Environ., 509-520, 1627, 2015.

De Foy, B., Heo, J., and Schauer, J. J. : Estimation of direct emissions and atmospheric processing of reactive mercury using inverse modeling, Atmos. Environ., 85, 73-82, 2014.

Demers, J. D., Driscoll, C. T., Fahey, T. J., and Yavitt, J. B.: Mercury cycling in litter and soil in different forest types in the Adirondack Region, New York, USA, Ecol. Appl., 17, 13411351, 2007.

de Oliveira, R. R., da Silveira, C. L. P., Magalhães, A. C., and Firme, R. P.: Turnover of heavy metals in the litter of a urban forest at Rio de Janeiro, Floresta e Ambiente, 12, 50-56, 2005.

De Simone, F., Gencarelli, C. N., Hedgecock, I. M., and Pirrone, N. : Global atmospheric cycle of mercury: a model study on the impact of oxidation mechanisms, Environ. Sci. Pollut. R., 21, 4110-4123, 2014.

Ding, Z., Wu, H., Feng, X., Liu, J., Liu, Y., Yuan, Y., Zhang, L., Lin, G., and Jiayong, P.: Distribution of $\mathrm{Hg}$ in mangrove trees and its implication for $\mathrm{Hg}$ enrichment in the mangrove ecosystem, Appl. Geochem., 26, 205-212, 2011.

Eckley, C. S., Gustin, M., Marsik, F., and Miller, M. B.: Measurement of surface mercury fluxes at active industrial gold mines in Nevada (USA), Sci. Total Environ., 409, 514-522, 2011.

Edwards, G. C. and Howard, D. A.: Air-surface exchange measurements of gaseous elemental mercury over naturally enriched and background terrestrial landscapes in Australia, Atmos. Chem. Phys., 13, 5325-5336, doi:10.5194/acp-13-5325-2013, 2013.

Edwards, G. C., Rasmussen, P. E., Schroeder, W. H., Wallace, D. M., Halfpenny-Mitchell, L., Dias, G. M., Kemp, R. J., and Ausma, S.: Development and evaluation of a sampling system to determine gaseous Mercury fluxes using an aerodynamic micrometeorological gradient method, J. Geophys. Res., 110, D10306, doi:10.1029/2004JD005187, 2005.

Engle, M. A., Tate, M. T., Krabbenhoft, D. P., Schauer, J. J., Kolker, A., Shanley, J. B., and Bothner, M. H.: Comparison of atmospheric mercury speciation and deposition at nine sites across central and eastern North America, J. Geophys. Res., 115, D18306, doi:10.1029/2010JD014064, 2010.

Enrico, M., Le Roux, G., Marusczak, N., Heimbürger, L.-E., Claustres, A., Fu, X., Sun, R., and Sonke, J. E.: Atmospheric mercury transfer to peat bogs dominated by gaseous elemental mercury dry deposition, Environ. Sci. Technol., 50, 2405-2412, 2016.

Ericksen, J. A., Gustin, M. S., Schorran, D. E., Johnson, D. W., Lindberg, S. E., and Coleman, J. S.: Accumulation of atmospheric mercury in forest foliage, Atmos. Environ., 37, 16131622, 2003.

Fang, G. C., Tsai, J.-H., Lin, Y.-H., and Chang, C.-Y.: Dry deposition of atmospheric particle-bound mercury in the middle Taiwan, Aerosol Air Qual. Res., 12, 1298-1308, 2012a.

Fang, G. C., Zhang, L., and Huang, C. S.: Measurements of sizefractionated concentration and bulk dry deposition of atmospheric particle bound mercury, Atmos. Environ., 61, 371-377, $2012 b$.

Fang, G. C., Lin, Y.-H., and Chang, C.-Y.: Use of mercury dry deposition samplers to quantify dry deposition of particulate-bound mercury and reactive gaseous mercury at a traffic sampling site, Environ. Forensics, 14, 182-186, 2013.
Fang, G. C., Lin, Y.-H., Chang, C.-Y., and Zheng, Y.-C.: Concentrations of particulates in ambient air, gaseous elementary mercury (GEM), and particulate-bound mercury $(\mathrm{Hg}(\mathrm{p}))$ at a traffic sampling site: a study of dry deposition in daytime and nighttime, Environ. Geochem. Hlth, 36, 605-612, 2014.

Fang, G. C., Lin, Y.-H., and Zheng, Y.-C.: Ambient air particulates and particulate-bound mercury $\mathrm{Hg}(\mathrm{p})$ concentrations: dry deposition study over a Traffic,Airport, Park (T.A.P.) areas during years of 2011-2012, Environ. Geochem. Hlth, 38, 183-194, 2016.

Feddersen, D. M., Talbot, R., Mao, H., and Sive, B. C.: Size distribution of particulate mercury in marine and coastal atmospheres, Atmos. Chem. Phys., 12, 10899-10909, doi:10.5194/acp-1210899-2012, 2012.

Fisher, L. S. and Wolfe, M. H.: Examination of mercury inputs by throughfall and litterfall in the Great Smoky Mountains National Park, Atmos. Environ., 47, 554-559, 2012.

Fostier, A.-H., Forti, M. C., Guimarães, J. R. D., Merlfi, A. J., Boulet, R., Espirito Santo, C. M., and Krug, F. J.: Mercury fluxes in a natural forested Amazonian catchment (Serra do Navio, Amapá State, Brazil), Sci. Total Environ., 260, 201-211, 2000.

Fostier, A. H., Cecon, K., and Forti, M. C.: Urban influence on litterfall trace metals fluxes in the Atlantic forest of São Paulo (Brazil), J. Physique IV France, 107, 491-494, 2003.

Fostier, A. H., Melendez-Perez, J. J., and Richter, L.: Litter mercury deposition in the Amazonian rainforest, Environ. Pollut., 206, 605-610, 2015.

Fritsche, J., Obrist, D., Zeeman, M. J., Conen, F., Eugster, W., and Alewell, C.: Elemental mercury fluxes over a sub-alpine grassland determined with two-micrometeorological methods, Atmos. Environ., 42, 2922-2933, 2008.

Fu, X., Marusczak, N., Heimbürger, L.-E., Sauvage, B., Gheusi, F., Prestbo, E. M., and Sonke, J. E.: Atmospheric mercury speciation dynamics at the high-altitude Pic du Midi Observatory, southern France, Atmos. Chem. Phys., 16, 5623-5639, doi:10.5194/acp16-5623-2016, 2016.

Fu, X. W., Feng, X., Dong, Z. Q., Yin, R. S., Wang, J. X., Yang, Z. R., and Zhang, H.: Atmospheric gaseous elemental mercury (GEM) concentrations and mercury depositions at a high-altitude mountain peak in south China, Atmos. Chem. Phys., 10, 24252437, doi:10.5194/acp-10-2425-2010, 2010a.

Fu, X. W., Feng, X., Zhu, W., Rothenberg, S., Yao, H., and Zhang, H.: Elevated atmospheric deposition and dynamics of mercury in a remote upland forest of southwestern China, Environ. Pollut., 158, 2324-2333, 2010b.

Fu, X. W., Zhang, H., Yu, B., Wang, X., Lin, C.-J., and Feng, X. B.: Observations of atmospheric mercury in China: a critical review, Atmos. Chem. Phys., 15, 9455-9476, doi:10.5194/acp-15-94552015, 2015.

Fulkerson, M.: Atmospheric mercury deposition in an urban environment, PhD Thesis, University of Central Florida, Florida, USA, 96 pp., 2006.

Gay, D. A., Schmeltz, D., Prestbo, E., Olson, M., Sharac, T., and Tordon, R.: The Atmospheric Mercury Network: measurement and initial examination of an ongoing atmospheric mercury record across North America, Atmos. Chem. Phys., 13, 1133911349, doi:10.5194/acp-13-11339-2013, 2013.

Gencarelli, C. N., De Simone, F., Hedgecock, I. M., Sprovieri, F., Yang, X., and Pirrone, N.: European and Mediterranean mercury 
modelling: Local and long-range contributions to the deposition flux, Atmos. Environ., 117, 162-168, 2015.

Gong, P., Wang, X.-P., Xue, Y.-G., Xu, B.-Q., and Yao, T.-D.: Mercury distribution in the foliage and soil profiles of the Tibetan forest: Processes and implications for regional cycling, Environ. Pollut., 188, 94-101, 2014.

Graydon, J. A., St. Louis, V. L., Hintelmann, H., Lindberg, S. E., Sandilands, K. A., Rudd, J. W. M., Kelly, C. A., Hall, B. D., and Mowat, L. D.: Long-Term Wet and Dry Deposition of Total and Methyl Mercury in the Remote Boreal Ecoregion of Canada, Environ. Sci. Technol., 42, 8345-8351, 2008.

Grigal, D. F., Kolk, R. K., Fleck, J. A., and Nater, E. A.: Mercury budget of an upland-peatland watershed, Biogeochemistry, 50, 95-109, 2000.

Gustin, M. S., Amos, H. M., Huang, J., Miller, M. B., and Heidecorn, K.: Measuring and modeling mercury in the atmosphere: a critical review, Atmos. Chem. Phys., 15, 5697-5713, doi:10.5194/acp-15-5697-2015, 2015.

Han, J.-S., Seo, Y.-S., Kim, M.-K., Holsen, T. M., and Yi, S.-M.: Total atmospheric mercury deposition in forested areas in South Korea, Atmos. Chem. Phys., 16, 7653-7662, doi:10.5194/acp16-7653-2016, 2016.

Han, Y.-J., Holsen, T. M., Ever, D. C., and Driscoll, C. T.: Reduced mercury deposition in New Hampshire from 1996 to 2002 due to changes in local sources, Environ. Pollut., 156, 1348-1356, 2008.

Hall, B. D. and St. Louis, V. L.: Methylmercury and total mercury in plant litter decomposing in upland forests and flooded landscapes, Environ. Sci. Technol., 38, 5010-5021, 2004.

Holloway, T., Voigt, C., Morton, J., Spak, S. N., Rutter, A. P., and Schauer, J. J.: An assessment of atmospheric mercury in the Community Multiscale Air Quality (CMAQ) model at an urban site and a rural site in the Great Lakes Region of North America, Atmos. Chem. Phys., 12, 7117-7133, doi:10.5194/acp-12-71172012, 2012.

Holmes, H. A., Pardyjak, E. R., Perry, K. D., and Abbott, M. L.: Gaseous dry deposition of atmospheric mercury: A comparison of two surface resistance models for deposition to semiarid vegetation, J. Geophys. Res., 116, S14306, doi:10.1029/2010JD015182, 2011.

Huang, J. and Gustin, M. S.: Use of passive sampling methods and models to understand sources of mercury deposition to high elevation sites in the western United States, Environ. Sci. Technol., 49, 432-441, 2015.

Huang, J., Choi, H.-D., Landis, M. S., and Holsen, T. M.: An application of passive samplers to understand atmospheric mercury concentration and dry deposition spatial distributions, J. Environ. Monitor., 14, 2976-2982, doi:10.1039/c2em30514c, 2012.

Hultberg, H., Munthe, J., and Iverfeldt, A.: Cycling of methylmercury and mercury - Responses in the forest roof catchment to three years of decreased atmospheric deposition, Water Air Soil Poll., 80, 415-424, 1995.

Hutnik, R. J., McClenahen, J. R., Long, R. P., and Davis, D. D.: Mercury Accumulation in Pinus nigra (Austrian Pine), Northeast. Nat., 21, 529-540, 2014.

Iverfeldt, ̊.: Mercury in forest canopy throughfall water and its relation to atmospheric deposition, Water Air Soil Poll., 56, 553564, 1991.
Jaffe, D. A., Lyman, S., Amos, H. M., Gustin, M. S., Huang, J., Selin, N. E., Leonard, L., Ter Schure, A., Mason, R. P., Talbot, R., Rutter, A., Finley, B., Jaeglé, L., Shah, V., McClure, C., Ambrose, J., Gratz, L., Lindberg, S., Weiss-Penzias, P., Sheu, G.-R., Feddersen, D., Horvat, M., Dastoor, A., Hynes, A. J., Mao, H., Sonke, J. E., Slemr, F., Fisher, J. A., Ebinghaus, R., Zhang, Y., and Edwards, G.: Progress on understanding atmospheric mercury hampered by uncertain measurements, Environ. Sci. Technol., 48, 7204-7206, 2014.

Jiskra, M., Wiederhold, J. G., Skyllberg U., Kronberg, R.-M., Hadjas, I., and Kretzschmar, R.: Mercury deposition and re-emission pathways in boreal forest soils investigated with $\mathrm{Hg}$ isotope signatures, Environ. Sci. Technol., 49, 7188-7196, 2015.

Johnson, K. B: Fire and its effects on mercury and methylmercury dynamics for two watersheds in Acadia National Park, Maine, MSc Thesis, the University of Maine, Maine, USA, 73 pp., 2002.

Juillerat, J. I., Ross, D. S., and Bank, M. S.: Mercury in litterfall and upper soil horizons in forested ecosystems in Vermont, USA, Environ. Toxicol. Chem., 31, 1720-1729, 2012.

Kalicin, M. H., Driscoll, C. T., Yavitt, J., Newton, R., and Munson, R.: The Dynamics of Mercury in Upland Forests of the Adirondack Region of New York, in: Mercury in Adirondack wetlands, lakes and terrestrial systems (MAWLTS), New York State Energy Research and Development Authority, New York, USA, 8-1-8$15,2008$.

Keeler, G., Glinsorn, G., and Pirrone, N.: Particulate mercury in the atmosphere: Its significance, transport, transformation and sources, Water Air Soil Pollut., 80, 159-168, 1995.

Kerkweg, A., Buchholz, J., Ganzeveld, L., Pozzer, A., Tost, H., and Jöckel, P.: Technical Note: An implementation of the dry removal processes DRY DEPosition and SEDImentation in the Modular Earth Submodel System (MESSy), Atmos. Chem. Phys., 6, 4617-4632, doi:10.5194/acp-6-4617-2006, 2006.

Kim, K. H., Lindberg, S. E., and Meyers, T. P.: Micrometeorological measurements of mercury vapor fluxes over background forest soils in Eastern Tennessee, Atmos. Environ., 29, 267-282, 1995.

Kim, P.-R., Han, Y.-J., Olsen, T. M., Yi, S.-M.: Atmospheric particulate mercury: Concentrations and size distributions, Atmos. Environ., 61, 94-102, 2012.

Kim, S.-H., Han, Y.-J., Holsen, T. M., and Yi, S.-M.: Characteristics of atmospheric speciated mercury concentrations (TGM, $\mathrm{Hg}$ (II) and $\mathrm{Hg}(\mathrm{p})$ ) in Seoul, Korea, Atmos. Environ., 43, 3267-3274, 2009.

Kolka, R. K., Nater, E. A., Grigal, D. F., and Verry, E. S.: Atmospheric inputs of mercury and organic carbon into a forested upland/bogwatershed, Water Air Soil Poll., 113, 273-294, 1999.

Kos, G., Ryzhkov, A., Dastoor, A., Narayan, J., Steffen, A., Ariya, P. A., and Zhang, L.: Evaluation of discrepancy between measured and modelled oxidized mercury species, Atmos. Chem. Phys., 13, 4839-4863, doi:10.5194/acp-13-4839-2013, 2013.

Lai, S.-O., Huang, J., Hopke, P. K., and Holsen, T. M.: An evaluation of direct measurement techniques for mercury dry deposition, Sci. Total Environ., 409, 1320-1327, 2011.

Landis, M. S., Keeler, G. J., Al-Wali, K. I., and Stevens, R. K.: Divalent inorganic reactive gaseous mercury emissions from a mercury cell chlor-alkali plant and its impact on near-field atmospheric dry deposition, Atmos. Environ., 38, 613-622, 2004. 
Lang, X.: Mercury in atmospheric precipitation and litterfall in Mt. Ailao and Mt. Damei, MSc Thesis, Guizhou University, Guiyang, China, 78 pp., 2014.

Larssen, T., de Wit, H. A., Wiker, M., Halse, K., Lei, H., Wuebbles, D. J., Liang, X.-Z., Tao, Z., Olsen, S., Artz, R., Ren, X., and Cohen, M.: Mercury budget of a small forested boreal catchment in southeast Norway, Sci. Total Environ., 404, 290-296, 2008.

Lee, G.-S., Kim, P.-R., Han, Y.-J., Holsen, T. M., Seo, Y.-S., and Yi, S.-M.: Atmospheric speciated mercury concentrations on an island between China and Korea: sources and transport pathways, Atmos. Chem. Phys., 16, 4119-4133, doi:10.5194/acp-16-41192016, 2016.

Lee, Y. H., Bishop, K. H., Munthe, J., Iverfeldt, Å., Verta, M., Parkman, H., and Hultberg, H.: An Examination of Current Hg Deposition and Export in Fenno-Scandian Catchments, Biogeochemistry, 40, 125-135, 1998.

Lee, Y. H., Bishop, K. H., and Munthe, J.: Do concepts about catchment cycling of methylmercury and mercury in boreal catchments stand the test of time? Six years of atmospheric inputs and runoff export at Svartberget, northern Sweden, Sci. Total Environ., 260, 11-20, 2000.

Lindberg, S. E. and Stratton, W. J.: Atmospheric mercury speciation: Concentrations and behaviour of reactive gaseous mercury in ambient air, Environ. Sci. Technol., 32, 49-57, 1998.

Lindberg, S. E., Owens, J. G., and Stratton, W. J.: Application of throughfall methods to estimate dry deposition of mercury, in: Mercury as a global pollutant, edited by: Huckabee, J. and Watras, C., Lewis Publications, 261-272, 1994.

Lindberg, S. E., Kim, K.-H., Meyers, T. P., and Owens, J. G.: A micrometeorological gradient approach for quantifying air/surface exchange of mercury vapor: Tests over contaminated soils, Environ. Sci. Technol., 29, 126-135, 1995.

Liu, B., Keeler, G. J., Dvonch, J. T., Barres, J. A., Lynam, M. M., Marsik, F. J., and Morgan, J. T.: Temporal variability of mercury speciation in urban air, Atmos. Environ., 41, 1911-1923, 2007.

Lombard, M. A. S., Bryce, J. G., Mao, H., and Talbot, R.: Mercury deposition in Southern New Hampshire, 2006-2009, Atmos. Chem. Phys., 11, 7657-7668, doi:10.5194/acp-11-76572011, 2011.

Luo, Y., Duan, L., Xu, G., and Hao, J.: Inhibition of mercury release from forest soil by high atmospheric deposition of $\mathrm{Ca} 2+$ and $\mathrm{SO}_{2}^{-}$, Chemosphere, 134, 113-119, 2015.

Lyman, S. N., Gustin, M. S., Prestbo, E. M., and Marsik, F. J.: Estimation of dry deposition of atmospheric mercury in Nevada by direct and indirect methods, Environ. Sci. Technol., 41, 19701976, 2007.

Lyman, S. N., Gustin, M. S., Prestbo, E. M., Kilner, P. I., Edgerton, E., and Hartsell, B.: Testing and application of surrogate surfaces for understanding potential gaseous oxidized mercury dry deposition, Environ. Sci. Technol., 43, 6235-6241, 2009.

Lyman, S. N., Gustin, M. S., and Presto, E. M.: A passive sampler for ambient gaseous oxidized mercury concentrations, Atmos. Environ., 44, 246-252, 2010.

Lynam, M. M., Dvonch, J. T., Hall, N. L., Morishita, M., and Barres J. A.: Trace elements and major ions in atmospheric wet and dry deposition across central Illinois, USA, Air Qual. Atmos. Health, 8, 135-147, 2015.

Ma, M., Wang, D., Du, H., Sun, T., Zhao, Z., Wang, Y., and Wei, S.: Mercury dynamics and mass balance in a subtropical for- est, southwestern China, Atmos. Chem. Phys., 16, 4529-4537, doi:10.5194/acp-16-4529-2016, 2016.

Maestas, M. M.: Characterization of speciated atmospheric mercury concentration measurements in northern Utah, MSc Thesis, The University of Utah, Utah, USA, 152 pp., 2011.

Marsik, F. J.: Mercury Dry Deposition Measurement Intercomparison and Workshop Final Report, available at http://www.glc.org/glad/Projectdocs/Marsik/GLAD_Progress_ Report_Oct2009_final.pdf (last access: 2 June 2016), 2009.

Marsik, F. J., Keeler, G. J., Lindberg, S. E., and Zhang, H.: The air-surface exchange of gaseous mercury over a mixed sawgrasscattail stand within the Florida Everglades, Environ. Sci. Technol., 39, 4739-4746, 2005.

Marsik, F. J., Keeler, G. J., and Landis, M. S.: The dry-deposition of speciated mercury to the Florida Everglades: measurements and modeling, Atmos. Environ., 41, 136-149, 2007.

Martin, R. S., Witt, M. L. I., Sawyer, G. M., Thomas, H. E., Watt, S. F. L., Bagnato, E., Calabrese, S., Aiuppa, A., Delmelle, P., Pyle, D. M., and Mather, T. A.: Bioindication of volcanic mercury $(\mathrm{Hg})$ deposition around Mt. Etna (Sicily), Chem. Geol., 310-311, 1222, 2012.

McLaughlin, E., Driscoll, C., Yavitt, J., Newton, R., and Munson, R.: Mercury in upland and riparian wetland vegetation, in: Mercury in Adirondack wetlands, lakes and terrestrial systems (MAWLTS), New York State Energy Research and Development Authority, New York, USA, 9-1-9-6, 2008.

Melendez-Perez, J. J., Fostier, A. H., Carvalho Jr., J. A., Windmoller, C. C., Santos, J. C., Carpi, A.: Soil and biomass mercury emissions during a prescribed fire in the Amazonian rain forest, Atmos. Environ., 96, 415-422, 2014.

Mélières, M.-A., Pourchet, M., Charles-Dominique, P., and Gaucher, P. : mercury in canopy leaves of French Guiana in remote areas, Sci. Total Environ., 311, 261-267, 2003.

Meyers, T. P., Hall, M. E., Lindberg, S. E., and Kim, K.: Use of the modified Bowen-ratio technique to measure fluxes of trace gases, Atmos. Environ., 30, 3321-3329, 1996.

Michelazzo, P. A. M., Fostier A. H., Magarelli, G., Santos, J. C., and Andrade de Carvalho Jr., A. : Mercury emission from forest burning in soutern Amazon, J. Geophys. Res. Lett., 37, L09809, doi:10.1029/2009GL042220, 2010.

Miller, E. K, Vanarsdale, A., Keeler, G. J., Chalmers, A., Poissant, L., Kanman, N. C., and Brulotte, R.: Estimation and mapping of wet and dry mercury deposition across northeastern North America, Ecotoxicology, 14, 53-70, 2005.

Munthe, J. Hultberg, H., and Iverfeldt, A.: Mechanisms of deposition of methylmercury and mercury to coniferous forests, Water Air Soil Poll., 80, 363-371, 1995.

Niu, Z., Zhang, X., Wang, Z., Ci, Z.: Mercury in leaf litter in typical suburban and urban broadleaf forests in China, J. Environ. Sci., 23, 2042-2048, 2011.

Nóvoa-Muñoz, J. C., Pontevedra-Pombal, X., Martinez-Cortizas, E., and Garcia-Rodeja Gayoso, E.: Mercury accumulation in upland acid forest ecosystems nearby a coal-fired power-plant in Southwest Europe (Galicia, NW Spain), Sci. Total Environ., 394, 303-312, 2008.

Obrist, D.: Mercury distribution across 14 U.S. Forests. Part II: Patterns of methyl mercury concentrations and areal mass of total and methyl mercury, Environ. Sci. Technol., 46, 5921-5930, 2012. 
Obrist, D., Johnson, D. W., Lindberg, S. E., Luo, Y., Hararuk, O., Bracho, R., Battles, J. J., Dail, D. B., Edmonds, R. L., Monson, R. K., Ollinger, S. V., Pallardy, S. G., Pregitzer, K. S., and Todd, D. E.: Mercury distribution across 14 US Forests. Part I: Spatial patterns of concentrations in biomass, litter, and soils, Environ. Sci. Technol., 45, 3974-3981, 2011.

Peterson, C. and Gustin, M. A.: Mercury in the air, water and biota at the Great Salt Lake (Utah, USA), Sci. Total Environ., 405, 255-268, 2008.

Peterson, C., Alishahi, M., and Gustin, M. A.: Testing the use of passive sampling systems for understanding air mercury concentrations and dry deposition across Florida, USA, Sci. Total Environ., 424, 297-307, 2012.

Poissant, L. and Casimir, A.: Water-air and soil-air exchange rate of total gaseous mercury measured at background sites, Atmos. Environ., 32, 883-893, 1998.

Poissant, L., Pilote, M., Xu, X., and Zhang, H.: Atmospheric mercury speciation and deposition in the Bay St. Francois wetlands, J. Geophys. Res., 109, D11301, doi:10.1029/2003JD004364, 2004.

Pokharel, A. K. and Obrist, D.: Fate of mercury in tree litter during decomposition, Biogeosciences, 8, 2507-2521, 2011.

Porvari, P. and Verta, M.: Total and methyl mercury concentrations and fluxes from small boreal forest catchments in Finland, Environ. Pollut., 123, 181-191, 2003.

Prestbo, E. M. and Gay, D. A.: Wet deposition of mercury in the U.S. and Canada, 1996-2005: Results and analysis of the NADP mercury deposition network (MDN), Atmos. Environ., 43, 42234233, 2009.

Rasmussen, P. E.: Temporal variation of mercury in vegetation, Water Air Soil Poll., 80, 1039-1042, 1995.

Rasmussen, P. E., Mierle, G., and Nriagu, J. O. : The analysis of vegetation for total mercury, Water Air Soil Poll., 56, 379-390, 1991.

Rea, A. W., Keeler, G. J., and Scherbatskoy, T.: The deposition of mercury in throughfall and literfall in the Lake Champlain watershed: a short-term study, Atmos. Environ., 30, 3257-3263, 1996.

Rea, A. W., Lindberg, S. E., and Keeler, G. J.: Assessment of dry deposition and foliar leaching of mercury and selected trace elements based on washed foliar and surrogate surfaces, Environ. Sci. Technol., 34, 2418-2425, 2000.

Rea, A. W., Lindberg, S. E., and Keeler, G. J.: Dry deposition and foliar leaching of mercury and selected trace elements in deciduous forest throughfall, Atmos. Environ., 35, 3453-3462, 2001.

Rea, A. W., Lindberg, S. E., Scherbatskoy, T., and Keeler, G. J.: Mercury accumulation in foliage over time in two northern mixed-hardwood forests, Water Air Soil Poll., 133, 49-67, 2002.

Richardson, J. B. and Friedland, A. J.: Mercury in coniferous and deciduous upland forests in northern New England, USA: implications of climate change, Biogeosciences, 12, 6737-6749, doi:10.5194/bg-12-6737-2015, 2015.

Risch, M. R., DeWild, J. F., Krabbenoft, D. P., Kolka, R. K., and Zhang, L.: Litterfall mercury dry deposition in the eastern USA, Environ. Pollut., 161, 284-290, 2012.

Roulet, M., Lucotte, M., Saint-Aubin, A., Tran, S., Rhéault, T. I., Farella, N., Da silva, E. D. J., Dezencourt, J., Sousa Passos, C.J., Soares, G. S., Guimarães, J.-R., D., Mergler, D., and Amorim, M. : The geochemistry of mercury in central Amazonian soils developed on the Alter-do-Chão formation of the lower Tapajós
River Valley, Pará state, Brazil, Sci. Total Environ., 223, 1-24, 1998.

Roulet, M., Lucotte, M., Farella, N., Serique, G., Coelho, H., Sousa Passos, C. J., de Jesus Dasilva, E., Scavone de Andrade, P., Mergler, D., Guimarãwa, J.-R., D., and Amorim, M. : Effects of recent human colonization on the presence of mercury in Amazonian ecosystems, Water Air Soil Poll., 112, 297-313, 1999.

Ryaboshapko, A., Bullock Jr., R., Ebinghaus, R., Ilyin, I., Lohman, K., Munthe, J., Petersen, G., Seigneur, C., and Wängberg, I.: Comparison of mercury chemistry models, Atmos. Environ., 36, 3881-3898, 2002.

Ryaboshapko, A., Bullock Jr., O. R., Christensen, J., Cohen, M., Dastoor, A., Ilyin, I., Petersen, G., Syrakov, D., Artz, R. S., Davignon, D., Draxler, R. R., and Munthe, J.: Intercomparison study of atmospheric mercury models: 1 . Comparison of models with short-term measurements, Atmos. Environ., 376, 228-240, 2007a.

Ryaboshapko, A., Bullock Jr., O. R., Christensen, J., Cohen, M., Dastoor, A., Ilyin, I., Petersen, G., Syrakov, D., Travnikov, O., Artz R. S., Davignon, D., Draxler, R. R., Munthe, J., and Pacyna, J.: Intercomparison study of atmospheric mercury models: 2. Modelling results vs. long-term observations and comparison of country deposition budgets, Sci. Total Environ., 377, 319-333, 2007b.

Sakata, M. and Asakura, K.: Evaluating relative contribution of atmospheric mercury species to mercury dry deposition in Japan, Water Air Soil Poll., 193, 51-63, 2008.

Sakata, M. and Marumoto, K.: Dry Deposition Fluxes and Deposition Velocities of Trace Metals in the Tokyo Metropolitan Area Measured with a Water Surface Sampler, Environ. Sci. Technol., 38, 2190-2197, 2004.

Sakata, M. and Marumoto, K.: Wet and dry deposition fluxes of mercury in Japan, Atmos. Environ., 39, 3139-3146, 2005.

Sather, M. E., Murkerjee, S., Smith, L., Mathew, J., Jackson, C., Callison, R., Scrapper, L., Hathcoat, A., Adam, J., Keese, D., Ketcher, P., Brunette, R., Karlstrom J., and Van der Jagt, G.: Gaseous oxidized mercury dry deposition measurements in the Four Corners area and Eastern Oklahoma, USA, Atmos. Poll. Res., 4, 168-180, 2013.

Sather, M. E., Mukerjee, S., Allen, K. L., Smith, L., Mather, J., Jackson, C., Callison, R., Scrapper, L., Hathcoat, A., Adam, J, Keese, D., Ketcher, P., Brunette, R., Karlstrom, J., and Van der Jagt, G.: Gaseous Oxidized Mercury Dry Deposition Measurements in the Southwestern USA: A Comparison between Texas, Eastern Oklahoma, and the Four Corners Area, Sci. World J., 2014, 14 pp., 580723, doi:10.1155/2014/580723, 2014.

Schwesig, D. and Matzner, E.: Pools and fluxes of mercury and methylmercury in two forested catchments in Germany, Sci. Total Environ., 260, 213-223, 2000.

Schwesig, D. and Matzner, E.: Dynamics of mercury and methylmercury in forest floor and runoff of a forested watershed in Central Europe, Biogeochemistry, 53, 181-200, 2001.

Seigneur, C., Karamchandani, P., Lohman, K., Vijayaraghavan, K., and Shia, R.-L.: Multiscale modeling of the atmospheric fate and transport of mercury, J. Geophys. Res., 106, 27795-27809, 2001.

Seigneur, C., Vijayaraghavan, K., Lohman, K., Karamchandani, P., and Scott, C.: Global source attribution for mercury deposition in the United States, Environ. Sci. Technol., 38, 555-569, 2004. 
Seigneur, C., Lohman, K., Vijayaraghavan, K., Jansen, J., and Levin, L.: Modeling Atmospheric Mercury Deposition in the Vicinity of Power Plants, JAPCA J. Air Waste Ma., 56, 743-751, 2006.

Selvendiran, P., Driscoll, C. T., Montesdeoca, M. R., and Bushey, J. T.: Inputs, storage, and transport of total and methyl mercury in two temperate forest wetlands, J. Geophys. Res., 113, G00C01, doi:10.1029/2008JG000739, 2008.

Sexauer Gustin, M., Weiss-Penzias, P. S., and Peterson, C.: Investigating sources of gaseous oxidized mercury in dry deposition at three sites across Florida, USA, Atmos. Chem. Phys., 12, 92019219, doi:10.5194/acp-12-9201-2012, 2012.

Sheehan, K. D., Fernandez, I. J., Kahl, J. S., and Amirbahman, A.: Litterfall mercury in two forested watersheds at Acadia National Park, Maine, USA, Water Air Soil Poll., 170, 249-265, 2006.

Silva-Filho, E. V., Machado, W., Oliveira, R. R., Sella, S. M., and Lacerda, L. D.: Mercury deposition through litterfall in an Atlantic Forest at Ilha Grande, Southeast Brazil, Chemosphere, 65, 2477-2484, 2006.

Slinn, S. A. and Slinn, W. G. N.: Predictions for particle deposition on natural waters, Atmos. Environ., 14, 1013-1016, 1980.

Song, S., Selin, N. E., Soerensen, A. L., Angot, H., Artz, R., Brooks, S., Brunke, E.-G., Conley, G., Dommergue, A., Ebinghaus, R., Holsen, T. M., Jaffe, D. A., Kang, S., Kelley, P., Luke, W. T., Magand, O., Marumoto, K., Pfaffhuber, K. A., Ren, X., Sheu, G.-R., Slemr, F., Warneke, T., Weigelt, A., Weiss-Penzias, P., Wip, D. C., and Zhang, Q.: Top-down constraints on atmospheric mercury emissions and implications for global biogeochemical cycling, Atmos. Chem. Phys., 15, 7103-7125, doi:10.5194/acp-157103-2015, 2015

Sprovieri, F., Pirrone, N., Ebinghaus, R., Kock, H., and Dommergue, A.: A review of worldwide atmospheric mercury measurements, Atmos. Chem. Phys., 10, 8245-8265, doi:10.5194/acp10-8245-2010, 2010.

Sprovieri, F., Gratz, L. E., and Pirrone, N.: Development of a Ground-Based Atmospheric Monitoring Network for the Global Mercury Observation System (GMOS). In proceedings of the 16th International Conference on Heavy Metals in the Environment, Rome, Italy, 23-27 September 2012, E3S Web of Conferences, doi:10.1051/e3sconf/20130117007, 2013.

St. Louis, V. L., Rudd, J. W. M., Kelly, C. A., Hall, B. D., Rolfhus, K. R., Scott, K. J., Lindberg, S. E., and Dong, W.: Importance of the forest canopy to fluxes of methylmercury and total mercury to boreal ecosystems, Environ. Sci. Technol., 35, 3089-3098, 2001.

Szopka, K., Karczewska, A., and Kabała, C.: Mercury accumulation in the surface layers of mountain soils: A case study from the Karkonosze Mountains, Poland, Chemosphere, 83, 1507-1512, 2011.

Teixeira, D. C., Montezuma, R. C., Oliveira, R. R., and Silva-Filho, E. W.: Litterfall mercury deposition in Atlantic forest ecosystem from SE Brazil, Environ. Pollut. 164, 11-15, 2012.

Travnikov, O. and Ilyin, I.: The EMEP/MSC-E mercury modelling system, in: Mercury fate and transport in the global atmosphere: emissions, measurements and models, edited by: Pirrone, N. and Mason, R., Springer, New York, 571-587, 2009.

Travnikov, O., Lin, C.-J., Dastoor, A., Bullock, O. R., Hedgecock, I. M., Holmes, C., Ilyin, I., Jaegle, L., Jung, G. J., Pan, L., Pongprueksa, P., Ryzhkov, A., Seigneur, C., and Skov, H.: Global and regional modelling, in: Hemispheric Transport of Air Pollution
2010 Part B: Mercury Air Pollution Studies No. 18, edited by: Pirrone, N. and Keating, T., United Nations Publications, New York, USA, and Geneva, Switzerland, 101-148, 2010.

Travnikov, O., Dastoor, A., Friedman, C., Ryzhkov, A., Selin, N., and Song, S.: AMAP/UNEP, 2015. Global Mercury Modelling: Update of Modelling Results in the Global Mercury Assessment 2013. Arctic Monitoring and Assessment Programme, Oslo, Norway/UNEP Chemicals Branch, Geneva, Switzerland, 32 pp., 2015.

Wallschläger, D., Kock, H. H., Schroeder, W. H., Lindberg, S. E., Ebinghaus R., and Wilken, R.-D.: Estimating gaseous mercury emissions from contaminated floodplain soils to the atmosphere with simple field measurement techniques, Water Air Soil Poll., 135, 39-54, 2002.

Wang, X., Lin, C.-J., and Feng, X.: Sensitivity analysis of an updated bidirectional air-surface exchange model for elemental mercury vapor, Atmos. Chem. Phys., 14, 6273-6287, doi:10.5194/acp-14-6273-2014, 2014.

Wang, Z., Zhang, X., Xiao, J., Zhijia, C., and Yu, P.: Mercury fluxes and pools in three subtropical forested catchments, southwest China, Environ. Pollut., 157, 801-808, 2009.

Weiss-Penzias, P. S., Gustin, M. S., and Lyman, S. N.: Sources of gaseous oxidized mercury and mercury dry deposition at two southeastern U.S. sites, Atmos. Environ., 45, 4569-4579, 2011.

Weiss-Penzias, P. S., Ortiz Jr., C., Acosta, R. P., Heim, W., Ryan, J. P., Fernandez, D., Collett Jr., J. L., and Flegal, A. R.: Total and monomethyl mercury in fog water from the central California coast, Geophys. Res. Lett., 39, L03804, doi:10.1029/2011GL050324, 2012.

Wesely, M. L.: Parameterization of surface resistances to gaseous dry deposition in regional-scale numerical models, Atmos. Environ. 23, 1293-1304, 1989.

Witt, E. L., Kolka, R. K., Nater, E. A., and Wickman, T. R.: Influence of the Forest Canopy on Total and Methyl Mercury Deposition in the Boreal Forest, Water Air Soil Poll., 199, 3-11, 2009.

Wright, G., Gustin, M. S., Weiss-Penzias, P., and Miller, M. B.: Investigation of mercury deposition and potential sources at six sites from the Pacific Coast to the Great Basin, USA, Sci. Total Environ., 470-471, 1099-1113, 2014.

Wright, L. P. and Zhang, L.: An approach estimating bidirectional air-surface exchange for gaseous elemental mercury at AMNet sites, J. Adv. Model. Earth Syst., 7, 35-49, doi:10.1002/2014MS000367, 2015.

Xiao, Z., Sommar, J., Lindqvist, O., and Giouleka, E.: Atmospheric mercury deposition to grass in southern Sweden, Sci. Total Environ., 213, 85-94, 1998.

Xu, X., Yang, X., Miller, D. R., Helble, J. J., and Carley, R. J.: Formulation of bi-directional atmosphere-surface exchanges of elemental mercury, Atmos. Environ., 33, 4345-4355, 1999.

Zhang, H., Lindberg, S. E., Marsik, F. J., and Keeler, G. J.: Mercury air/surface exchange kinetics of background soils of the Tahquamenon River watershed in the Michigan Upper Peninsula, Water Air Soil Poll., 126, 151-169, 2001.

Zhang, L., Gong, S., Padro, J., and Barrie, L. A.: A size-segregated particle dry deposition scheme for an atmospheric aerosol module, Atmos. Environ., 35, 549-560, 2001.

Zhang, L., Brook, J. R., and Vet, R.: A revised parameterization for gaseous dry deposition in air-quality models, Atmos. Chem. Phys., 3, 2067-2082, doi:10.5194/acp-3-2067-2003, 2003. 
Zhang, L., Wright, L., P., Blanchard, P.: A review of current knowledge concerning dry deposition of atmospheric mercury, Atmos. Environ., 43, 5853-5864, 2009.

Zhang, L., Blanchard, P., Johnson, D., Dastoor, A., Ryzhkov, A., Lin, C. J., Vijayaraghavan, K., Gay, D., Holsen, T. M., Huang, J., Graydon, J. A., St. Louis, V. L., Castro, M. S., Miller, E. K., Marsik, F., Luk, J., Poissant, L., Pilote, M., and Zang, K. M.: Assessment of modeled mercury dry deposition over the Great Lakes region, Environ. Pollut., 161, 272-283, 2012a.

Zhang, L., Blanchard, P., Gay, D. A., Prestbo, E. M., Risch, M. R., Johnson, D., Narayan, J., Zsolway, R., Holsen, T. M., Miller, E. K., Castro, M. S., Graydon, J. A., Louis, V. L. St., and Dalziel, J.: Estimation of speciated and total mercury dry deposition at monitoring locations in eastern and central North America, Atmos. Chem. Phys., 12, 4327-4340, doi:10.5194/acp-12-43272012, 2012b.
Zhou, J., Feng, X., Liu, H., Zhang, H., Fu, X., Bao, Z., Wang, X., Zhang, Y.: Examination of total mercury inputs by precipitation and litterfall in a remote upland forest of Southwestern China, Atmos. Environ., 81, 364-372, 2013.

Zhu, W., Lin, C.-J., Wang, X., Sommar, J., Fu, X., and Feng, X.: Global observations and modeling of atmosphere-surface exchange of elemental mercury: a critical review, Atmos. Chem. Phys., 16, 4451-4480, doi:10.5194/acp-16-4451-2016, 2016. 